GEOLOGICAL SURVEY CIRCULAR 667

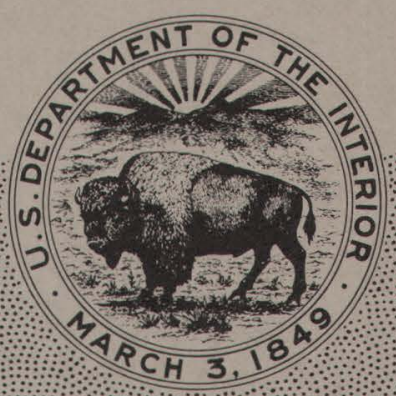

West Virginia's Buffalo Creek Flood:

A Study of the Hydrology and

Engineering Geology 

West Virginia's Buffalo Creek Flood:

A Study of the Hydrology and

Engineering Geology

By William E. Davies, James F. Bailey,

and Donovan B. Kelly

GEOLOGICAL SURVEY CIRCULAR 667 
United States Department of the Interior ROGERS C. B. MORTON, Secretary

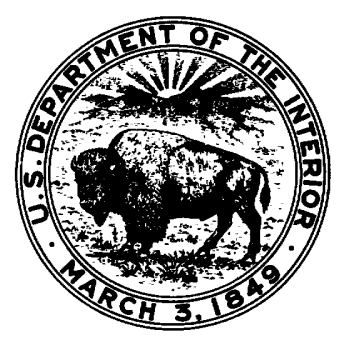

\section{Geological Survey \\ V. E. McKelvey, Director}




\section{CONTENTS}

\section{Summary}

Scope of present study

Setting

Geography

Geology

History and growth of a coal-waste dam that failed

1966 inspection of coal-waste bank

Growth of coal-waste banks: 1966 to 1972 flood

Source of floodwater

Snowmelt

Precipitation

Pool on Middle Fork

Failure of the dam

Geologic and engineering evidence

Slumps

Subsidence

Foundation seepage (piping) -.-.---_--

Flow lines
Page

1 Failure of the dam-Con.

Geologic and engineering evidence-Con.

Debris lines -

Eyewitness observations _-_._-_._-_...- 17

Summary of sequence of failure of coal-waste dam No. 3

Analysis of other reported modes of failure Explosions within the dam -... 25 Ditching - -

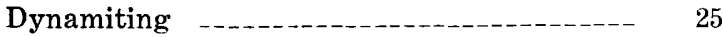

Conclusions as to cause of dam failure -_._- $\quad 26$

The flood -..-.-. 27

Flood conditions in the Guyandotte River basin $\quad 27$

Previous floods -...- 28

The flood on Buffalo Creek _-_-___- 28

Time of travel of the flood wave

Profiles

Depth of flow - 32

Scour and deposition - 32

References - 32

\section{ILLUSTRATIONS}

FIgURE 1. Map of West Virginia showing location of Buffalo Creek flood area

2. Map showing Buffalo Creek valley

3. Sketch map of Middle Fork, February 1972, before dam broke

4. Profile along Middle Fork, Saunders, W. Va.

5. Reconstructed view of coal-waste banks on Middle Fork, near Saunders, W. Va. -

6. Aerial photograph showing Buffalo Creek area, West Virginia (November 3, 1971)

7. Graph showing gradation curves, coal-waste dam No. 3, Saunders, W. Va.

8. Map showing rainfall in southwestern West Virginia, February 24 to February 26, 1972

9-12. Graph showing-

9. Height of the pool behind coal-waste dam No. 3

10. Area covered by the pool behind dam No. 3

11. Increase in volume of water in the pool behind coal-waste dam No 3

12. Rate of inflow to the pool behind coal-waste dam No. 3

13. Diagram showing plan and cross-section through coal-waste dam No. 3 after failure, on Middle Fork, Saunders, W. Va.

14-19. Photographs:

14. Looking upstream at the left abutment of coal-waste dam No. 3

15. Sump near former front of coal-waste dam No. 3

16. View across coal-waste dam No. 3 from right abutment

17. Top of right abutment of coal-waste dam No. 3 showing 14-inch-wide water channel developed along bulldozer tracks

18. Breach in coal-waste dam No. 2

19. View upstream across former clear pond behind coal-waste bank No. 1 
20. Haul road looking upstream midway along the right edge of coal-waste bank No. $1_{--}$

21. View down the canyon cut along the right side of coal-waste bank No. 1 at the mouth of Middle Fork

22. Face of coal-waste bank No. 1 at the intersection of Middle Fork and Buffalo Creek

23. Panoramic view downstream through the breach in coal-waste dam No. 3

24. Sketch map of Middle Fork on February 26, 1972, shortly after dam failure

25-27. Photographs:

25. Pool area above coal-waste dam No. 3 following failure of the dam

26. Middle Fork, panoramic view, mine No, 5 to Buffalo Creek, March 5,1972 and vertical aerial photograph, dam No. 3 to Buffalo Creek, February 28, 1972.

27. Debris from Middle Fork deposited in Buffalo Creek, looking downstrean over former site of Saunders

28. Graph showing the sudden high peak of 19.34 feet produced on the gaging station record for

Guyandotte River at Man by the flood inflow from Buffalo Creek

29. Estimated flood hydrographs for Buffalo Creek below Saunders, below Stowe, above Accoville, and near Man on February 26, 1972

30. Graph showing time of travel of the flood wave down Buffalo Creek from Middle Fork to Man

31. Profile of the peak flood discharge and of the streambed, Buffalo Creek, Middle Fork to Man

\section{TABLES}

TABLE 1. Percentage of coal in composite sample

2. Unit weights (bulk density) of coal samples

3. Floods in southwestern West Virginia, February 25-27, 1972 


\title{
West Virginia's Buffalo Creek Flood: A Study of the Hydrology and Engineering Geology
}

\author{
By William E. Davies, James F. Bailey, and Donovan B. Kelly
}

\section{SUMMARY}

On February 26, 1972, the most destructive flood in West Virginia's history swept through the Buffalo Creek valley in the southwestern corner of the State, 40 miles south of Charleston (fig. 1). Shortly before 8:00 a.m., a coal-waste dam collapsed on the Buffalo Creek tributary of Middle Fork releasing some $\mathbf{1 7 . 6}$ million cubic feet ( 132 million gallons) of water. The water passed through two more piles of coal waste blocking the Middle Fork to reach the Buffalo Creek valley floor. In its 1/2-mile run from the top of the coal-waste dam to the floor of Buffalo Creek, the large volume of floodwater dropped in elevation some 250 feet. The small settlement of Saunders, near the junction of Middle Fork and Buffalo Creek in the shadow of the lower coal-waste bank, was completely destroyed by the force of the water as were parts of the other 16 mining camps farther down the valley (fig. 2).

The 10- to 20 -foot flood wave traveled through the 15-mile Buffalo Creek valley at an average speed of about 7 feet per second ( 5 miles per hour) and reached the town of Man at the mouth of Buffalo Creek on the Guyandotte River around 11:00 a.m. During those 3 hours, at least 118 lives were lost, 500 homes were destroyed, 4,000 people were left homeless, property damage exceeded $\$ 50$ million and highway damage alone exceeded $\$ 15$ million. Two months after the flood, seven people were still reported missing.

Between February 24 and 26, the National Weather Service measured precipitation of 3.7 inches in the general area of Logan County and Buffalo Creek. That amount of precipitation is about a 2-year rainfall; that is, southwestern West Virginia can expect precipitation to equal or exceed 3.7 inches in a 3-day period on the average of once every 2 years. Streams similar to Buffalo Creek in and around Logan County responded to the 3 days of precipitation with flows on the order of a 10-year flood; that is, a flow that can be expected to occur on the average of about once in a 10-year period. Following the failure of the coal-waste dam, flow in Buffalo Creek near Saunders jumped from less than a 10-year flood to a discharge about 40 times greater than a 50-year flood. The dif- ference between the discharge less than a 10 -year flood and the discharge 40 times greater than the 50-year flood reflects the difference between the natural flood that would probably have occurred and the flood that resulted from failure of the dam.

Employees of the Buffalo Creek Mining Co., operators of the coal-waste dam that failed, report that water was within 1 foot of the graded crest of the dem 4 hours prior to the flood. Failure of the coal-waste dam probably occurred through foundation deficiences, causing sliding and slumping of the front face of the dam. The failure was accelerated by the waterlogged condition of the dam. The slumping lowered the top of the coal-waste dam and allowed the impounded water to breach and then rapidly erode the crest of the dam. Upon failure of the dam, the floodwater moved into pockets of burning coal waste at the lower coal-waste bank and caused explosions. The only signs of burning and explosions were at the lower coal-waste bant.

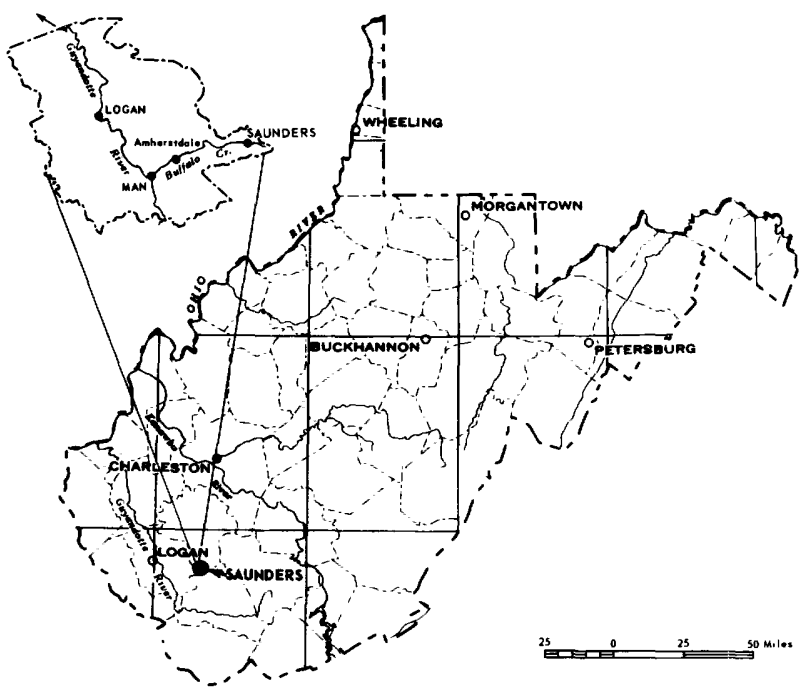

FigURE 1.-Location of Buffalo Creek flood area. 


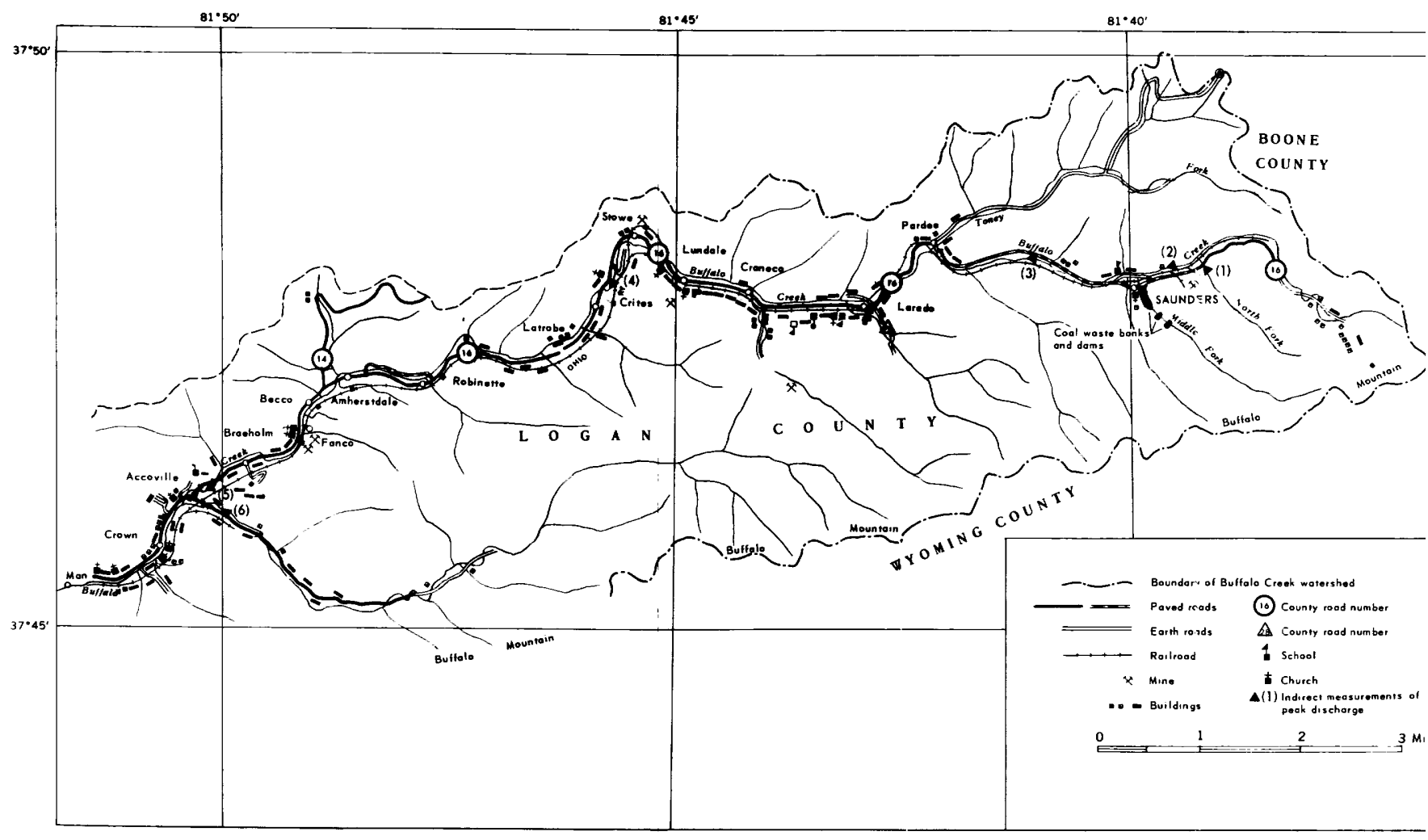

Figuke 2.-Buffalo Creek valley, Saunders to Man.

In their coal-mining operations, the Buffalo Creek Mining Co. had built three major coal-waste banks by dumping waste rock and coal in the narrow valley of Middle Fork (fig. 3). Coal-waste bank No. 1 was located at the mouth of the Middle Fork. Banks No. 2 and 3 were upstream 600 and 1,200 feet from bank No. 1 and served as dams prior to the flood. Part of the purpose of the dams was to reduce stream pollution by impounding the waste-water from the coal washing plant, thus allowing most of the sediment to settle. The porous nature of the coal-waste dams allowed most of the water normally to filter through the dam and this clear water was recycled to the washing plant from decanting basins downstream.

Although banks No. 2 and 3 were not engineered as dams and would not be acceptable as dams in an engineering sense, they will be referred to as coal-waste dam No. 2 and coal-waste dam No. 3. Coal-waste dam No. 3 impounded the 17.6 million cubic feet of water that produced the flood. A fourth small bank, about 2,600 feet upvalley from dam No. 3, formerly served as an impounding structure, but the area behind it was filled with sediment in 1972 .

\section{SCOPE OF PRESENT STUDY}

Immediately following the flood, employees of the U.S. Geological Survey and several members of the West Virginia Geologic and Economic Survey began investigating the physical dimensions of the flood: what caused the flood? where did the water come from? why and how did the dam fail? and what wer? the heights and discharges of the floodflow along Buffalo Creek hollow? The purpose of tre field investigations and of this report is to reconstruct the physical facts and events surrounding the flood. The Geological Survey released a preliminary report in March 1972 as a contribution to the Interior Department Task Force analysis of the failure of the coal-refuse dam at Saunders (U.S. Department of Interior, 1972).

The following were among the initial field investigations conducted: a 19-mile flood profile was surveyed on Buffalo Cree' from above Saunders to the mouth at Man; indirect measurements of peak discharges were made at six sites; several aerial photography flights were flown and several hundred photographs were taken at ground level; the reservoir volume behind coal-waste dam No. 3 was surveyed; geologic mapping was conducted along Middle Fork from dam No. 3 to F 'ffalo Creek; eyewitness accounts were collected on the failure of the dam and the passage of the flood; a bucket survey of precipitation vras conducted throughout Buffalo Creek hollow; water-qual- 


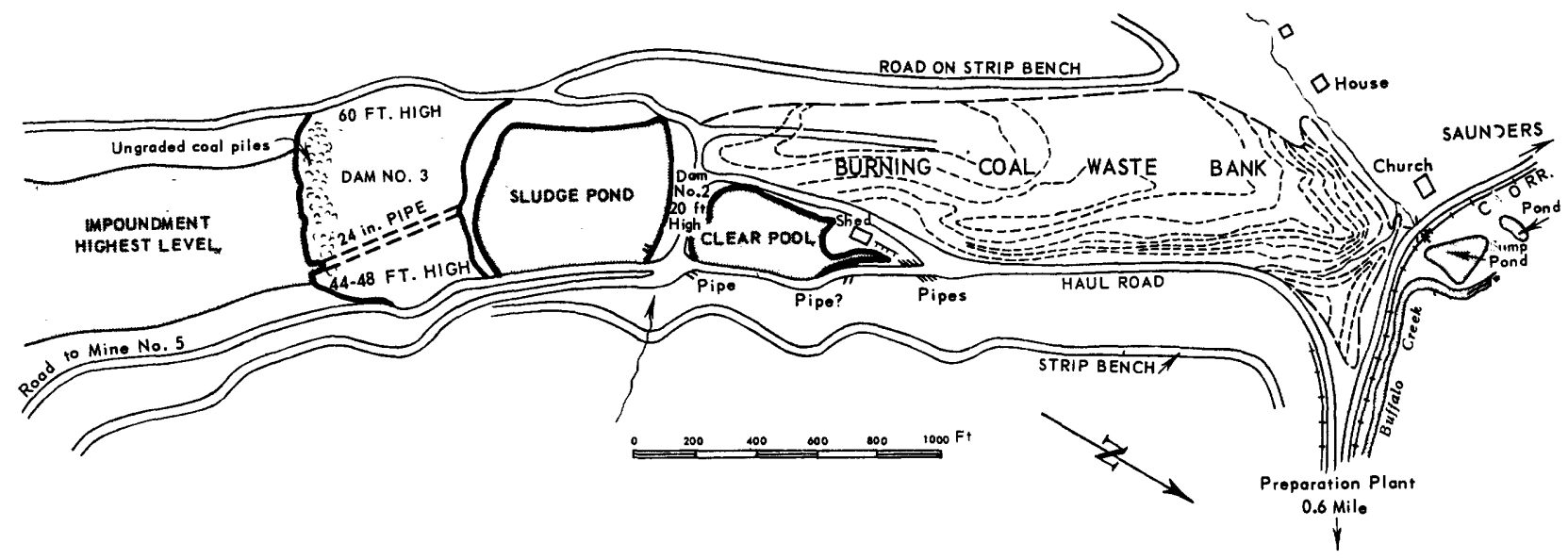

Figure 3.-Sketch map of Middle Fork, February 1972, before dam broke.

ity samples of the flood peak were collected at Saunders and Latrobe; and coal-waste samples were collected at the site of dam No. 3.

More detailed studies on the physical characteristics of material in the coal-waste dams in Middle Fork valley are now underway by the Department of Interior and the data cited in this report may be altered by these investigations.

Some of the facts, figures, and photographs used in this report were generously supplied by residents, newspapermen, and local, State, and Federal employees. Their help in producing this report is gratefully acknowledged.

\section{SETTING}

GEOGRAPHY

From its headwaters on the northern flanks of Buffalo Mountain, Buffalo Creek has cut a zig-zag valley as it flows west to meet the Guyandotte River at Man in southwestern West Virginia. The curves that interrupt the general east to west flow of Buffalo Creek mark detours where the stream loops north or south around the noses and peaks of some of the more resistant ridges. The most prominent loop in the valley is at Stowe, about halfway between Saunders and Man. Here the creek flow northwest for about 0.7 mile between Lundale and Stowe before turning almost due south for 1.3 miles from Stowe at the top of the loop to Latrobe at the bottom.

The sinuosity of Buffalo Creek, that is, its tendency to zig-zag around ridges instead of flowing in a straight line, forces the stream to flow for 15 miles from Saunders to Man-a straight line distance of less than 12 miles. This sinuosity also impairs the ability of Buffalo Creek to carry off floodflows; each bend and turn acts as an impediment to flow and kacks up water and retains any flow longer than a straight channel would.

The flood plain of Buffalo Creek, the narrow, valley-bottom flatlands formed from materials deposited over the years by the stream, is generally less than 400 feet wide. People kegan to use this narrow flood plain for living space when mining developed in the region after 1900. In 1914, the Chesapeake and Ohio Railroad completed a spur up the valley, and long coal trains began making daily runs down the valley to the main line at Barboursville. By 1920, Buffalo was checkered with smal but closely-spaced mining camps, located where the flood plain was widest. Towns such as Saunders, Lorado, Craneco, Crites, Amherstdale, Becco, Accoville, and Crown were built where the small flood plains of tributary stroams joined the flood plain of Buffalo Creek; and towns such as Pardee, Stowe, and Robinette were built on the wider flatland around some of the loops of Buffalo Creek.

During the last half-century, the mining companies sold most of the houses to individuals, and the camps became independent small communities. Before the flood, there were 17 settlements along Buffalo Creek. By 1972, the two-lane Buffalo Creek road had been improved 
and recently resurfaced. Before the flood, the road, railroad, and houses filled much of the flood plain, leaving only small space for the creek.

Over a long period of time, a stream such as Buffalo Creek will just fill its banks without overflowing about twice a year. Less often, but just as predictably, a stream can be expected to overflow its banks and flood the flood plain.

Jammed between steeply rising valley walls, the narrow flood plain of Buffalo Creek offers little opportunity to build above the level of the 50-year flood. Upstream from Amherstdale, the flood plain is less than 400 feet wide and above Saunders the flood plain almost disappears. Even downstream from Saunders, the valley becomes so narrow in places that there is barely room for the railroad and the road. At Saunders and Accoville, the ridges rise over 1,000 feet above the valley floor at an angle of about $26^{\circ}$; at Lorado and Amherstdale, the rise is even steeper, $30^{\circ}$ to $35^{\circ}$, to a ridge that runs some 700-900 feet above the flood plain.

The steepness of the valley walls and the thinness of the soil contribute to floodflows in the valley. Gentle slopes and thick soils tend to slow up and absorb the runoff from heavy rains and thus delay and attenuate flood peaks. Instead of gentle slopes, the valley walls act more like high-pitched roofs with slopes as high as $40^{\circ}$ and occasional 50 -foot sandstone cliffs. Instead of thick soils to absorb some of the precipitation runoff, soils on the uplands and valley walls are thin; generally they are less than 3 feet thick and seldom are as much as 5 feet thick (Latimer, 1915). Furthermore, the soils tend to a composition of low permeability and are dominantly a clayey, silty sand with large quantities of stone varying from small chips to boulders a foot long and commonly underlain by clay layers up to an inch thick between the base of the soil zone and the underlying bedrock.

All these factors-the sinuosity of the channel, the narrowness of the flood plain, the steepness and height of the valley walls, and the thinness and relative impermeability of the soil-combine to make Buffalo Creek a hollow susceptible to natural flooding. During the extreme, nonnatural, flood of 1972, these factors also contributed to the flooding but played a lesser role to the overwhelming volume and force of water involved.

\section{GEOLOGY}

The ridges, valleys, and mineral wealth of Buffalo Creek hollow are a direct reflection of the bedrock geology. Buffalo $\mathrm{C}$ :eek and its tributaries are cut into the higr. plateau that forms the western flank of the Appalachians. The valleys and hollows in this area are so numerous and well developed trat very little remains of the upland of the plateau. As a result, the topography is a series of narrow, steep, sinuous headwater ridges flanked by equally steep and narrow spurs. Each major stream is an entity in itself and is separated from adjacent drainage basins by uniformly crested ridges with few gaps or saddles opening between basins. The remrants of the plateau upland are at 2,400 to 2,600 feet above sea level. The major valleys are about 1,200 feet below the upland, and tributary hollows are as much as 1,000 feet deep.

The topography around Buffalo Creek reflects the bedrock. Beneath the spurs and ridges are coal seams and related sendstone and shale, all part of the Kanahwa Series (Pennsylvanian). The Kanahwa Series in this area is over 1,500 feet thick and consists of many repetitive cyclothems formed by sequences of coal, shale, sandstone, and clay with occasional thin irregular limestone beds (Hennen and others, 1914). Along Middle Fork, three cyclothems involving the Cedar Grove, Chilton, and Coalburg coals are present. Of these, only the Cedar Grove and Chilton are of concern in the failure of the dam and the subsequent flood; the Coalburg lies near the top of the ridges and is a hundred feet or more above the floor of Middle Fork. The following sequence is exposed in the lower part of the Middle Fork:

Mine No. 5.

Chilton upper coal, with intervening stale beds and fire clay, coal beds up to 3 feet tl ick ........

Shale and some sandstone

20

Massive sandstone

Chilton lower coal and intervening shale beds, coal up to 18 inches thick; coal stripped and augered

Clayey shale 
Slabby sandstone, formed ȧbutment of dam No. 3

Little Chilton coal, shale and coal interlayered, coal up to 18 inches thick

Massive gray, slightly micaceous sandstone, forms ledge at ponds No. 1 and 2

Shale and sandstone

Massive irregularly bedded sandstone, sheeted surfaces

Olive brown to gray shale

Gray, well-bedded sandstone, near level of Cedar Grove coal

Base at level of debris in Buffalo Creek.

The beds dip gently to the northwest about 66 feet per mile (1.3 percent). Major fractures trending N. $80^{\circ}$ E. and N. $10^{\circ} \mathrm{E}$. cut the sandstone units. Joints at N. $55^{\circ} \mathrm{W}$. and N. $30^{\circ} \mathrm{W}$. are prominent.

The floors of the narrow, steep-sided hollows contain only coarse stony debris except where they have been filled with coal waste. The flats along Buffalo Creek are underlain by tightly packed, rounded cobbles and pebbles of sandstone and by sandy silt up to 1 or 2 feet thick. Bedrock in the valley is from 4 to 20 feet beneath the surface.

The valley flat along Buffalo Creek has been cleared of most of its natural vegetation. The valley walls and uplands àre covered by continuous but thin growth of second stand timber, most of which is less than 3 inches in diameter in the lower trunk. Oak, hickory, honey locust, yellow locust, pine, and some hemlock are present. Three strip mine benches interrupt the vegetation along both sides of Middle Fork. Except where the benches are used as roads, they are overgrown with brush and small trees.

\section{HISTORY AND GROWTH OF A COAL-WASTE DAM THAT FAILED}

Mining activities began in Middle Fork in 1945 when the Lorado Mining Co. opened Mine No. 5 and accelerated when the preparation plant was completed 2 years later. In 1964, the property was acquired by the Buffalo Mining Co., which in turn was taken over by the Pittston Co., in 1970 (Park and others, 1972).

In 1972 the preparation plant, on Buffalo Creek about half a mile east of Saunders, was handling about 5,000 tons of raw coal per twoshift day from five mines, a strip bench, and two auger operations carried on by the Pittston Company. The preparation plant produced about 1,000 tons of solid coal-waste refuse each two-shift day and used in its cleaning prosess about a half million gallons of water per day, most of which was reused after the solids were settled out.

The Lorado Mining Co., began trucking refuse from the preparation plant to the mouth of Middle Fork about 25 years ago, and in the process, it built a large waste bank across the hollow. By 1966, waste bank No. 1 exterded 1,500 feet down the Middle Fork and was 200 feet high at the face on Buffalo Creek.

In 1959 , the company began pumping waste water into the hollow behind the bank to sattle out solids from the spent wash water. At first the water drained rapidly through the kank in spite of several attempts to create a reservoir for use in dry seasons. However, after 1960, coal from strip-mine operations was processed through the washer. The fine material from the strip mines made the bank less pervious, resulting in a large impoundment. Water was then decanted from the large settling pool that formed into smaller clear ponds for recycling in the preparation process. Between 400,000 and 500,000 gallons per day containing about 500 tons of solids were pumped to the settling pool. Before using pools for settlement of waste material, the sludge effluent was discharged into Buffalo Creek. When rtate regulations concerning pollution of streams were enacted in the early 1950's, the company chose first to put the sludge underground in mined out areas and later used impoundment and decanting basins as one of several possible methods of meeting requirements.

\section{INSPECTION OF COAL-WASTE BANK}

The Geological Survey first examined the coal-waste bank at Saunders in December 1966. On October 21 of that year, a large hillside waste bank at Aberfan, Wales (U.K.), slumped, sending a mass of liquified coal refuse 1,600 feet down the hill. Concerned over the prospect that such a thing might happen in the United States, the U.S. Bureau of Mines drew on the experience of its many mine inspectors to prepare lists of all waste banks in the Appalachians that, because of their location and size, 
could cause loss of life or property if they slid in a manner similar to the bank at Aberfan. The lists were supplemented by information furnished the U.S. Bureau of Mines by the local offices of the United Mine Workers Union through their national headquarters. The Bureau of Mines called upon the U.S. Geological Survey to assist in examination of each waste bank cited in the lists. In late November and early December of 1966, 38 waste banks in West Virginia were inspected by William E. Davies, geologist, and John Gallagher, hydrologist, both of the U.S. Geological Survey.

On December 9, 1966, Mr. Tom Gay, of the Logan office of the Bureau of Mines, and Mr. Davies inspected the single coal-waste bank then in existence on Middle Fork at Saunders (waste-bank No 1). Several hours were spent on the top of the bank, examining the material and method of deposition. Additional time was spent examining the sides along the haul road down to the north face, the large pond behind the waste bank, the small dike on the east that added to the height of the impounding structure, the north face of the bank, and the seepage issuing near the base of the structure. It was concluded that the waste bank at Saunders was stable as far as large slides were concerned but was subject to large washout on the north side from overflow of lake.

Observations on the engineering geology aspects of coal-waste banks were later described in two reports. The first report covered the geological aspects of coal-waste banks and was presented on November 21, 1967, to the Annual Meeting of the Geological Society of
America (Davies, 1967). An exranded report with considerable emphasis on the dangers from failure of waste banks acting as impounding structures was later presented to a meeting of the American Mining Congress (Davies, 1968).

\section{GROWTH OF COAL-WASTE BANKS, 1966 TO 1972 FLOOD}

With 1,000 tons of waste dumped daily, the deposits in Middle Fork grew rapidly. Within a year after the 1966 inspection, the waste bank had increased in elevation by 50 feet, and the pool behind it had been filled with material settled from wash water. A second, larger pool had been formed in 1967 by a dam created from coal waste placed on the older sludge (figs. 3, 4, and 5). In 1966, t] is dam was merely a small dump on the left wall of the valley about 600 feet upstream from the dike at the south end of the waste bank. However, in late 1967, this dam was completed and could impound water to a depth of about 20 feet above the old sludge line of the first pool. This dam and the retaining dike at the rear of the coal-waste bank were overtopped and partially carried away by high water from snowmelt early in 1967. A small flood occurred in Buffalo Creek as a consequence.

Within 2 years, the limit of this second pool to settle material from wash water was in sight, and a third pool was established by dumping coal waste on the sludge trapped in the 1959 and 1967 pools. This dam (No. 3) was 600 feet upstream from the dam forming the second impounding and begar impounding water in late 1969. Dam No. 3 grew both in

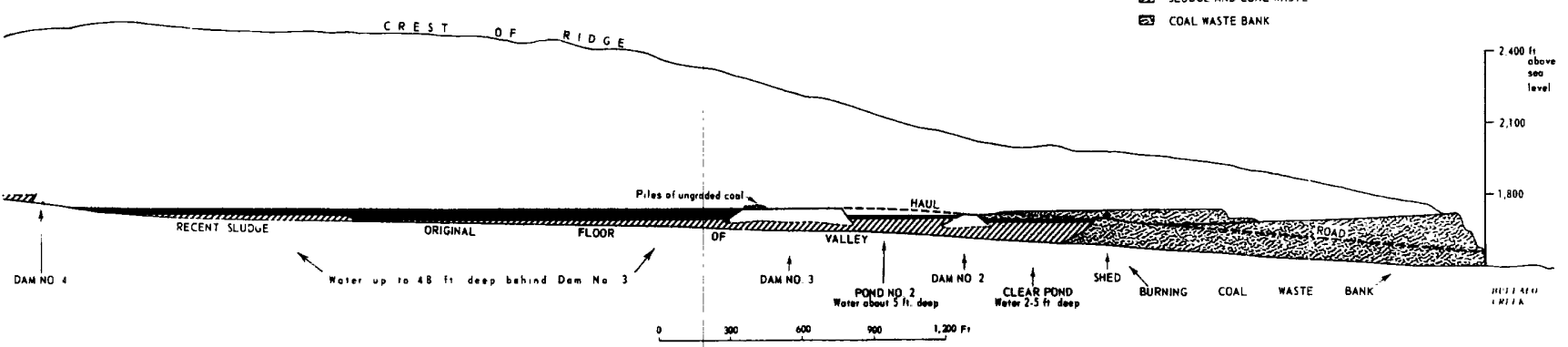

Figure 4.-Profile along Middle Fork, Saunders, W. Va. 


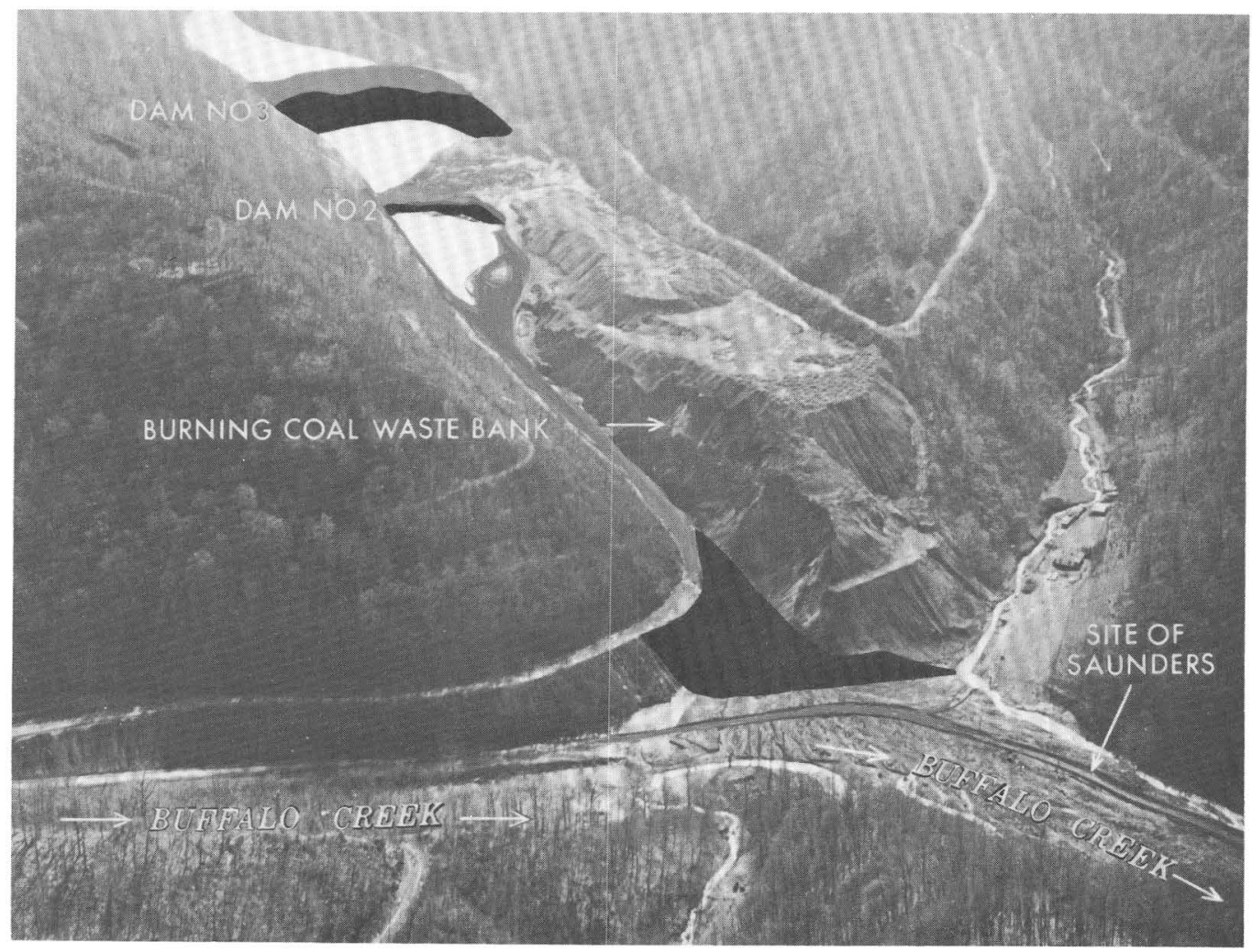

FIGURE 5.-Reconstructed view of coal-waste banks on Middle Fork, near Saunders, W. Va. (Original aerial photograph taken after flood by West Virginia Department of Highways.)

height and thickness, and probably was near its final height (but not thickness) in February 1971.

By early February 1972, dam No. 3 extended 465 feet across the valley along its front (downstream) crest, was 450 feet wide at the rear, and up to 550 feet wide along the center. From front to back along the compacted crest, it was 360 feet thick on the right and 480 feet thick on the left (looking downstream). On the right, the compacted crest rose 44 feet, and on the left, it rose 60 feet above the level of the sludge in pond No. 2. The compacted crest on the front (downstream) face was about 10 to 15 feet lower than the rear (upstream) face. Altogether, dam No. 3 contained about 10 million cubic feet of coal waste standing above the level of the sludge line of pool No. 2 and about 7 million cubic feet displacing the sludge below that line. About 800,000 tons of coal waste had been dumped to form the dam. The front face of the dam sloped $37^{\circ}$, the angle of repose for most coal-waste material, and the back sloped $32^{\circ}$, the angle of repose for such material where dumping was modified by impounded water. The front (northwest) face of the dam, based on an aerial photograph taken November 3, 1971 (fig. 6), was concave in plan and contained four small concave hollows. The rear face was nearly straight, except near the right abutment where a reentry cut diagonally into the dam.

Most dams constructed from coal waste impound water only during periods of heavy rain or during periods of large volume waste-water discharge. However, in the case of dam No. 3, there is evidence that a pool with a depth of about 30 feet at the dam endured for a long period of time. Fine coal and sludge formed an extensive terrace at the head of the impoundment area behind dam No. 3, just below dam No. 4. These deposits are 15 feet thick at the front, 400 feet long grading into the valley floor near dam No. 4, and 60 feet wide at the lower end. The top of the terrace is flat and the deposits have horizontal beds, indicating 


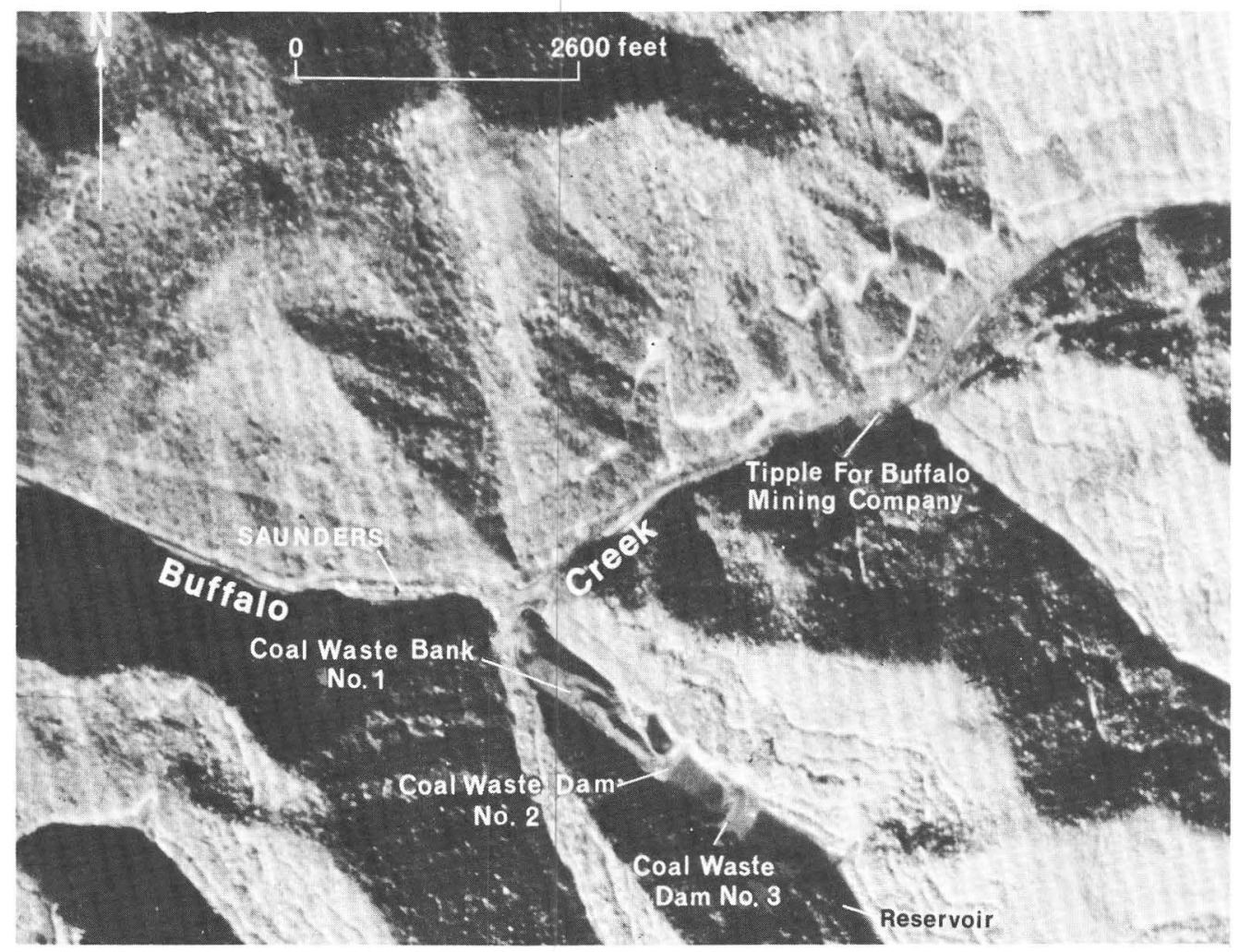

Figure 6.-Buffalo Creek area, West Virginia, Nov. 3, 1971. (Aerial photograph by Appalachian Regional Commission.)

deposition in a quiet, steady pool. The top of the terrace coincides with a distinct line of black sludge extending along the valley walls to dam No. 3. The terrace and sludge line are about 30 feet above the sludge fill at dam No. 3.

In constructing dam No. 3, the coal waste was dumped from trucks in closely spaced piles from 4 to 7 feet high and then graded in layers 2 to 4 feet thick. The dumping was carried across the dam in the form of "lifts" on successive levels of material 10 to 20 feet thick. Once the dam was closed, dumping was mainly across the back side of the dam, which steadily grew upstream. Trees in the path of the dam construction were not removed but were covered by dumping. The pool area also was not cleared of vegetation. The sludge on which the waste was dumped was only partially displaced and much of it formed the foundation of the dams. It is probable that the amounts of sludge underneath the dams were proportional to the original thickness of the sludge. Underneath dam No. 2, the sludge is probably on the order of 100 feet thick and about 50 feet thick beneath dam No. 3. Only the abutments of the dams were on bedrock or thin soil over bedrock, and in dam No. 3 these are the only parts that remain.

On February 26, 1972, the compacted crest over which the trucks moved stood 60 feet above the sludge level on the left abutment and sloped gradually to 44 feet above the sludge level on the right abutment. In addition, the rear part of the dam, mainly on the right half, was covered with abutting piles of recently dumped but ungraded coal rising 4 to 7 feet above the compacted crest.

Based on what remains in the abutments, the material within dam No. 3 was relatively homogeneous. Well-sorted segments consisting primarily of fine coal were confined to discontinuous layers less than 6 inches thick and to pockets and lenses up to 1 foot thick and 10 feet long. No segregation, layering, or zoning of material to obtain maximum stability occur in the remnants of the dam, and considering the method of construction, these features were probably lacking in the rest of the 
dam. The coal waste forming the dam was about 20 percent slabs (up to $2 \mathrm{ft}$ on a side) of clayey shale and low-grade (bone) coal, 50 percent chips and chunks (up to 1 in. on a side), and 30 percent fine coal and sludge. Particle-size distribution obtained from one sample in the right abutment, two samples in the left abutment, and a sample in a mound heaved up at the toe of the front of the dam are comparably homogeneous with a graded distribution ranging from boulders to silt with a mean in the 5- to 10-m (fine gravel) category (fig. 7 ). The amount of fine coal mixed in the other material in the dam varies according to grain size and ranged from 24 to 74 percent (table 1).

Slabs and chips of shale and coal were bonded by clay in the right abutment. This material was high in sulfides, and a light-gray efflorescence of sulfates was deposited along fractures and on faces of slabs and chips.
TABLE 1.-Percentage of coal in composite sample

[Based on six samples from left abutment; includes only material finer than $32 \mathrm{~mm}$ ]

Grain size $(\mathrm{mm})$

Percentage of coal

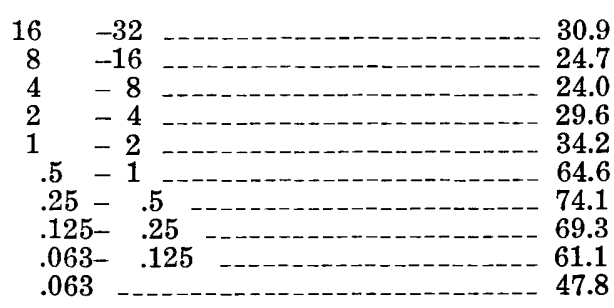

The material remaining in the left abutment of dam No. 3 was bonded by clayey material but was relatively low in sulfates. Only thin, discontinuous effluorescences were present on the upper part of this abutment. The shale in both abutments was slaking rapidly and breaking down to chips and flakes less

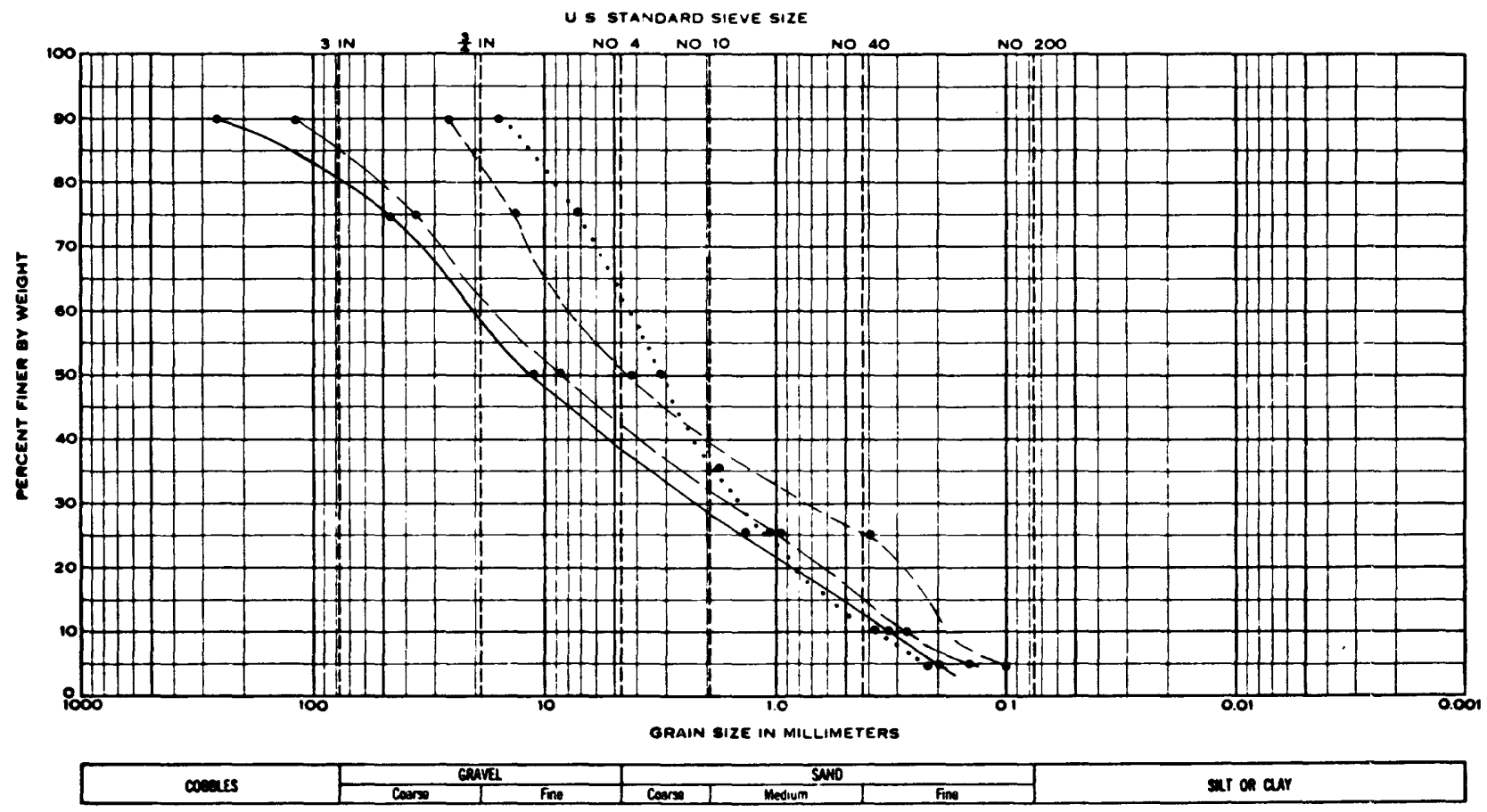

GRADATION CURVES, COAL WASTE DAM NO. 3, SAUNDERS, WEST VIRGINIA

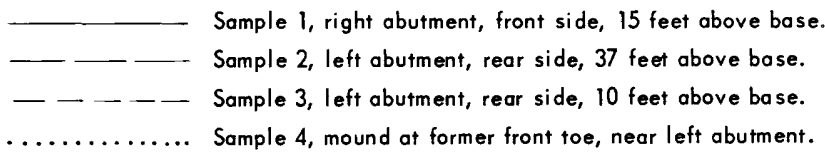

FigURE 7.-Gradation curves, coal-waste dam No. 3, Saunders, W. Va. 
than 1 inch in maximum dimension. The slabs remaining in the abutments were randomly oriented, and bedding or layering was not discernible.

Undisturbed samples for use in determining bulk density and percent voids could not be collected because of the presence of numerous large slabs of shale in the dam. Four samples weighing 11 to 19 pounds were collected for unit-weight (bulk-density) studies under three degrees of repacking (table 2). Observations indicate that the materials in the dam have a unit weight similar to that of the medium pack. Thus specific weight would range from 86 to 98 pounds per cubic foot, which is significantly less than the 112 to 125 pounds per cubic foot for soils derived from various Appalachian shales and much less than the specific weight of compacted fills. Percent of void space of the medium pack, interpreted from that in the solid pack, would be on the order of 20 to 22 percent, which is up to 50 percent greater than that of soils derived from Appalachian shales.

TABLE 2.-Unit weights (bulk density) of coal samples [Values in pounds per cubic foot. Sample locations eited in fig. 7]

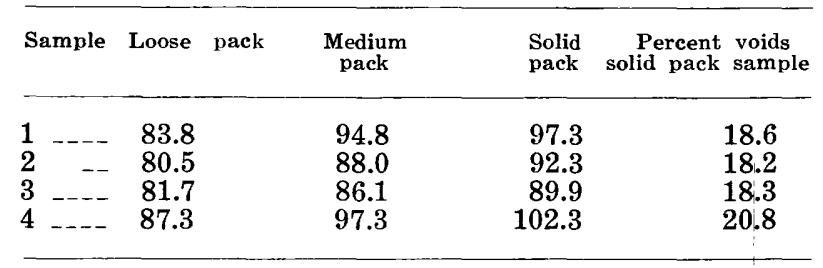

Visual inspection indicated that the coal waste in dam No. 3 had undergone little compaction after grading and being crossed by heavy trucks. However, compared to most waste banks, this small degree of compaction appeared to be significantly higher. In addition, the permeability appeared to be less than in many similar waste banks.

Dam No. 3 had no open or overfall type of spillway. Excess water was apparently taken care of by seepage through the dam and drainage was augmented by an overflow pipe reportedly placed in July 1971 and extending from the right rear of the structure diagonally to near the center of the downstream face. The pipe, reported to be 4 to 7 feet below the graded crest, was 24 inches in diameter and made of butt-welded 1/4-inch steel. After the failure of the dam, two segments of the pipe protruded above the debris. The segment on the right side is about $\mathbf{1 7 0}$ feet downstream from the toe of the right abutment and 50 feet from tro valley wall. It protrudes downstream at a true azimuth of $350^{\circ}$ (azimuth of the axis of the valley is $310^{\circ}$ ) and slopes $12^{\circ}$ downwards to tho south (upstream). The exposed part of the pipe showed no damage from movement in tho flood. Sediment occupied all but 6 inches of the pipe, and the top of the sediment fill was flat and parallel to the surface of the pipe. This would indicate the filling was from material carried through the pipe and deposited in it while the pipe was in a relatively horizontal position. The lack of filling from flood debris can be accounted for in that the pipe opening was in the direction of flow protecting it, from direct deposition. This part of the pipe had a hard thin crust of a former fill that occupied about half of the inner circumference and was not in accord with the present fill, indicating that the pipe had been cleared previously of an accumulation of sediment and then reset.

Another segment of pipe is exposed near the front of the left abutment. About 12 feet of this pipe protrudes at a tru€ azimuth of $200^{\circ}$, slopes downwards to the northeast at $20^{\circ}$, and shows no sign of distortion. Most of the fill at the top of this pipe is apparently from the flood because the fill occupies almost the entire inside and is nearly horizontal with respect to the final position of the pipe. However, the small part of the second pipe not filled with sediments shows evirence of an opening deeper in the pipe similar to that described for the first pipe.

Whether or not the two parts of pipe are continuous cannot be established at this time. It is probable that the pipe is not a single unit, and the buried part probably is fractured and otherwise disrupted. There is no evidence that the pipe had a protective collar or facing at its upstream end when it was in the c'am, nor does it appear to have had baffles along it to curtail seepage.

A fourth dam stretches across Middle Fork about 2,600 feet upstream from the maximum pool impounded by dam No. 3. D`m No. 4, an 
earthen dam constructed mainly of shale with coal waste, rises 25 feet above the bed of Middle Fork. The dam is about 200 feet long, and its crest ranges in width from 10 feet near the west side to over 40 feet on the east. The area behind the dam is filled with silt and coal waste and no water is impounded. A spillway on bedrock is on the left (west) side of the dam.

\section{SOURCE OF FLOODWATER}

Three possible sources of water could have contributed significantly to the Buffalo Creek flood: heavy runoff from melting snow, heavy runoff from locally intense cloudburst rainfall in any of the streams tributary to Buffalo Creek, and water released from the reservoir on Middle Fork following failure of coal-waste dam No. 3. As will be shown, the failure of dam No. 3 on Middle Fork contributed almost all of the peak floodflow in Buffalo Creek; direct runoff from snowmelt or rainfall and inflow from tributaries other than Middle Fork were not significant.

\section{SNOWMELT}

Residents of the Buffalo Creek hollow discount the importance of the snow cover in producing the floodflow. They report that by the end of February snow cover was limited to scattered drifts mainly on the northern slopes of the higher hills. According to the National Weather Service, the last snowstorm reported prior to the flood dropped about 1.5 inches of snow at Logan on February 19-20. On February 25 , the day before the flood, very little snow was visible in the hills.

\section{PRECIPITATION}

During the 72-hour period immediately preceding the flood, precipitation averaged 3.7 inches at Logan and at other stations 15-20 miles south and east of Buffalo Creek, according to the National Weather Service (fig. 8). About half of the rainfall (1.9 in.) at Logan fell in the 24 hours that preceded the flood. Precipitation tapered off to the north during the 3-day period, measuring 2.35 inches in Charleston. Maximum precipitation during the storm was 4.5 inches produced at Williamson, 22 miles west of Buffalo Creek. A bucket sur-

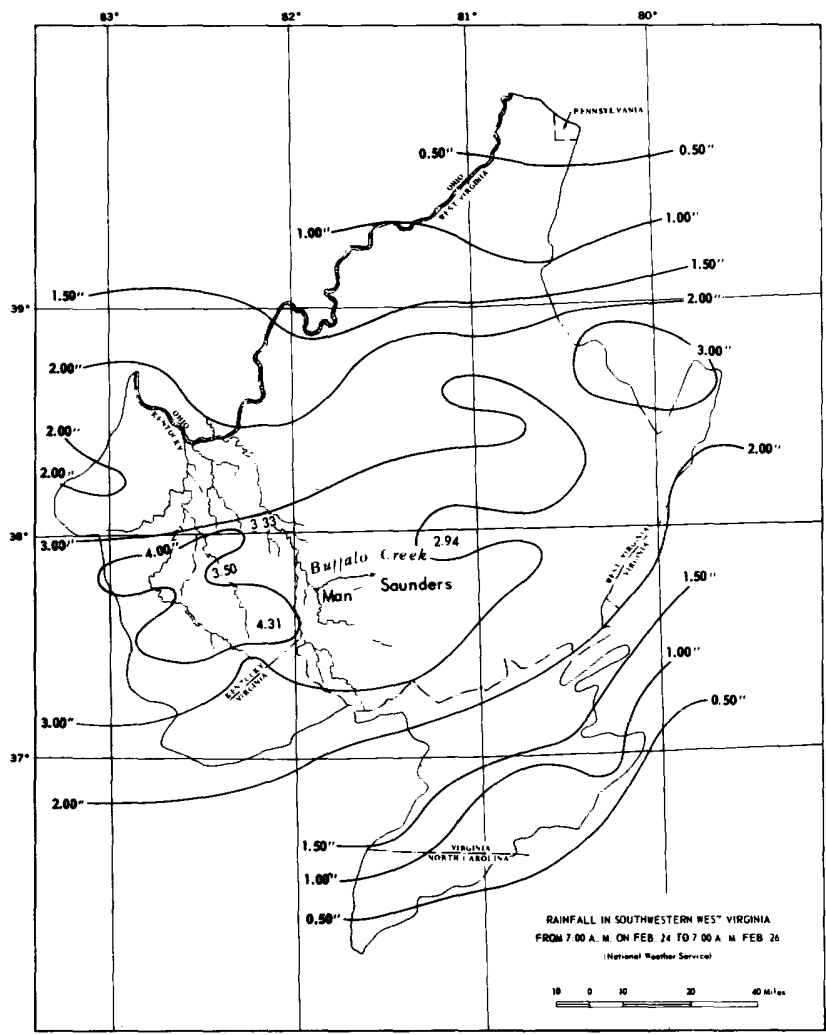

FIgURE 8.-Rainfall in southwestern West Virginia, Feb. 24 to Feb. 26, 1972.

vey in the Buffalo Creek hollow conducted by field parties during the week following the flood revealed no catchment of precipitation in open cans and other available containers that exceeded 3.7 inches recorded at Logan.

According to National Weather Service estimates, 3.7 inches of rain in 3 days is about a 2-year rainfall; that is, southwestern West Virginia can expect precipitation to equal or exceed 3.7 inches in a 3-day period over a long-term average of once every 2 years. In fact, precipitation exceeding 3.7 inches in a 2 or 3 day period has been measured at Logan eight times in the last 17 years. Indirect measurements of peak discharges of streams tributary to Buffalo Creek and inspection of streams near the Buffalo Creek basin produced no evidence of sudden high flows from cloudburst rainfall.

In conclusion, February was a slightly wetter month than normal; total precipitation at Logan during the month was 4.56 inches, 1.2 inches above the 30-year average. Altrough 
the storm of February 24-26 dumped most of its precipitation during the 24 hours immediately preceding the flood, no evidence was found of large cloudburst rainfalls that could contribute the large volume of water needed to produce the flash flood on Middle Fork and Buffalo Creek. The only available source of water large enough to produce the flood was the pool of water behind coal-waste dam No. 3 on the Middle Fork.

\section{POOL ON MIDDLE FORK}

Information on inflow and characteristics of the pool behind coal-waste dam No. 3 were determined from field surveys and interviews with local residents. The pool reached its maximum volume, about 17.6 million cubic feet of water and sludge, around 8:00 a.m. on Saturday, February 26 (fig. 9). At that time the water-surface elevation had risen to $1,753.1$ feet above mean sea level, and the depth of water in the pool just upstream of the coalwaste dam was 47.3 feet. The surface area of the pool at the time of the dam failure was 14.2 acres (fig. 10), and the pool extended 2,100 feet up the Middle Fork valley.

Slightly less than half the contents of the pool was sludge. The top of the sludge line in the pool stood at an elevation of 1,733.6 feet

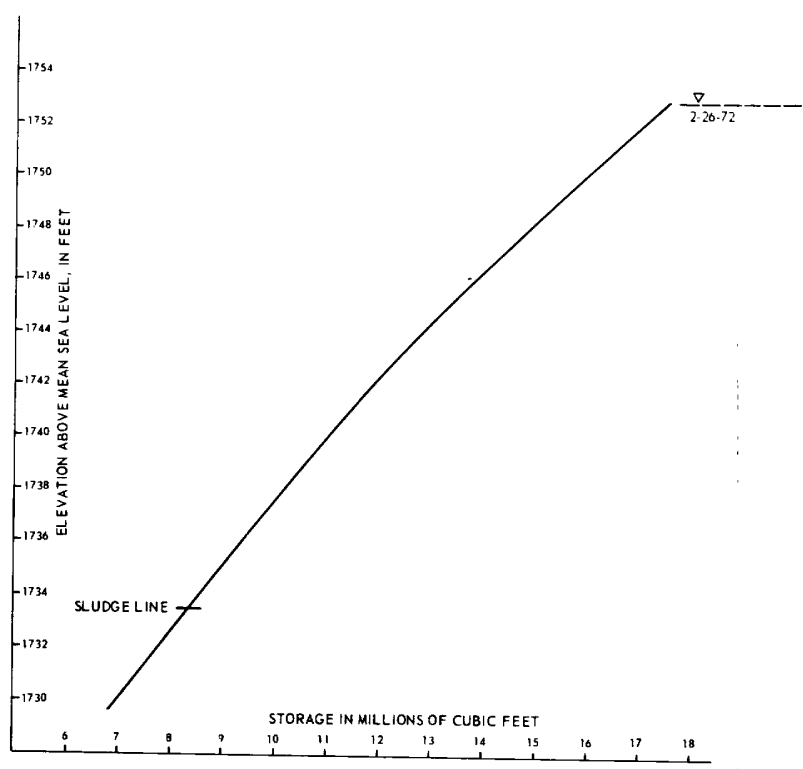

Figure 9.-Height of the pool behind coal-waste dam No. 3 rose to a maximum of $1,753.1$ feet.

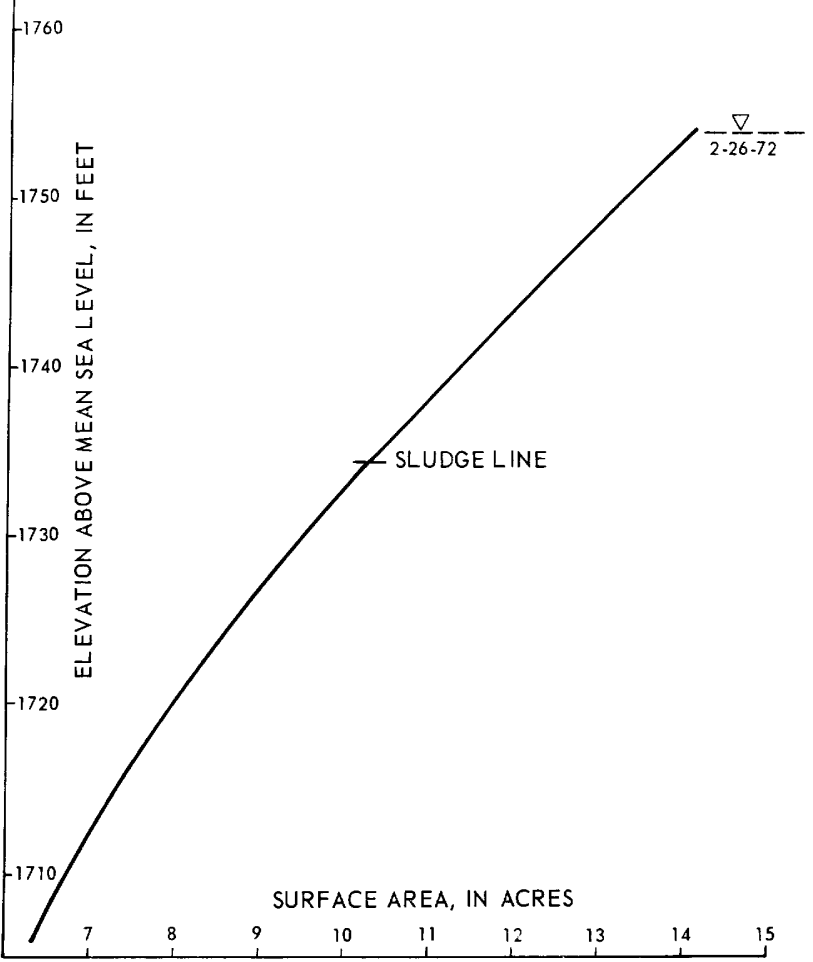

Figure 10.- The pool behind dam No. 3 covered a maximum of 14.2 acres at the time the dam collapsed.

m.s.l. (mean sea level). At that elevation, the volume of sludge was 8.4 million cubic feet and the surface area was 10.3 acres.

There are two known sources of inflow to the pool: natural drainage from Middle Fork basin, and water pumped from nearby mines and from the washing plant locsted one-half mile east of the mouth of Middle Fork. Inflow from natural drainage is the principal source of inflow. Information furnished by local residents indicates that pumping, if there was pumping during the storm periot, would not contribute significantly to the inflow. As much as 25,000 cubic feet per day might be pumped, an insignificant amount when compared to total pool volume of 17.6 million cubic feet.

Middle Fork drains an area of 1.18 square miles, 1.1 square miles of which is above coalwaste dam No. 3. Peak inflow during the storm period and rate of rise of pool contents are estimated from interviews with mine-company personnel and from indirect measurements on 
other small drainage areas in the Buffalo Creek basin near Middle Fork.

At 4:00 p.m. Thursday, February 24, a local mining-company employee placed a measuring stick on the lowest point of the back (upstream) side of coal-waste dam No. 3 so that the top of the stick was approximately 1 foot below the compacted part of the dam. This employee visited the dam frequently between 4:00 p.m. Thursday and 4:30 a.m. Saturday, observing the rate of rise of the pool. Analysis of the observations indicate a rise of slightly less than 1 inch per hour on Thursday afternoon, increasing to about 3 inches per hour by 3:00 a.m. Saturday. Using the stage-volume curve shown in figure 9 and the observations made on the measuring stick, the rate of rise of the pool is shown in figure 11.

Outflow from the reservoir cannot be reliably established from the information available. A 24-inch drain pipe (or pipes) is

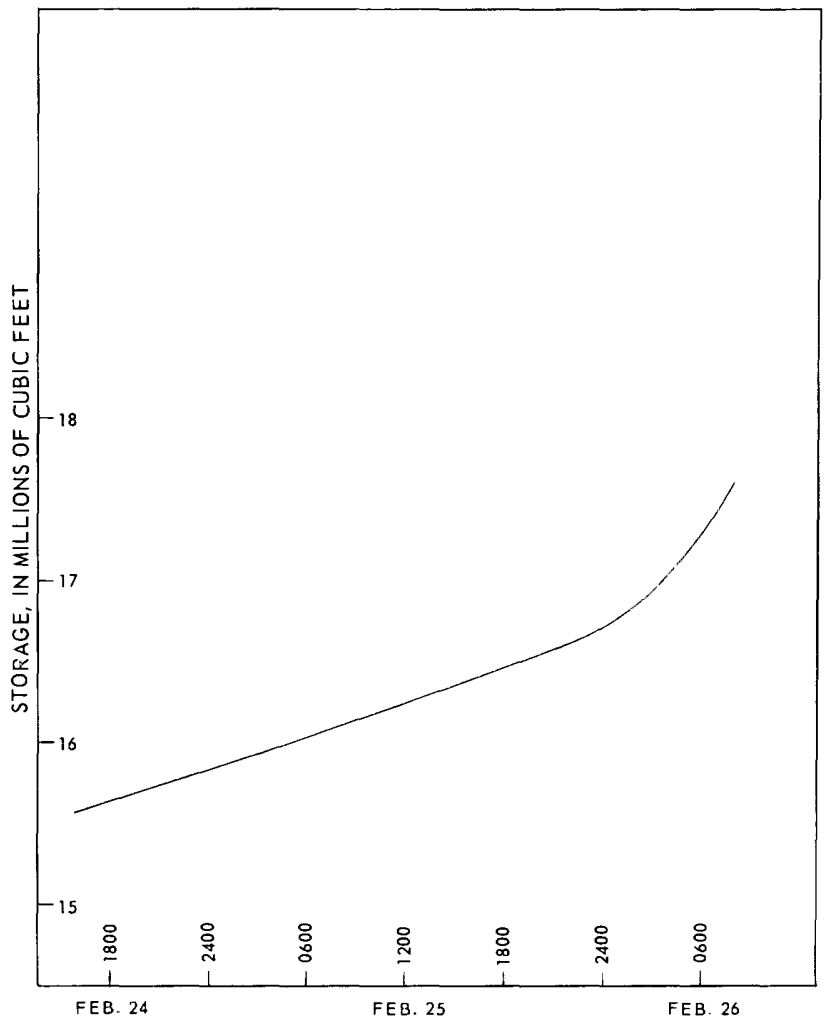

Figure 11.-The volume of water in the pool behind coal-waste dam No. 3 increased steadily between February 24-26. reported to have been in place and carrying flow at the time of the dam failure. The exact position of this drain pipe in the dam and the true head on the pipe have not been ascertained. However, computations based or its location as reported by eyewitnesses yield a a peak flow through the pipe of about $10 \mathrm{cfs}$ $(4,500 \mathrm{gpm})$.

Using the rate of change in contents relation developed in figure 11 and adjusting for outflow, the inflow graph shown in figur? 12 was developed for the period 4:00 p.m. Trursday, February 24, to 4:00 a.m. Saturday, February 26 , when observations on the elevation of the impounded water were discontinued. The inflow curve does not include seepage through the dam. Maximum seepage, estimated at less than $10 \mathrm{cfs}(4,500 \mathrm{gpm})$, would have occurred just prior to failure when the hydraulic gradient through the dam was the greatest.

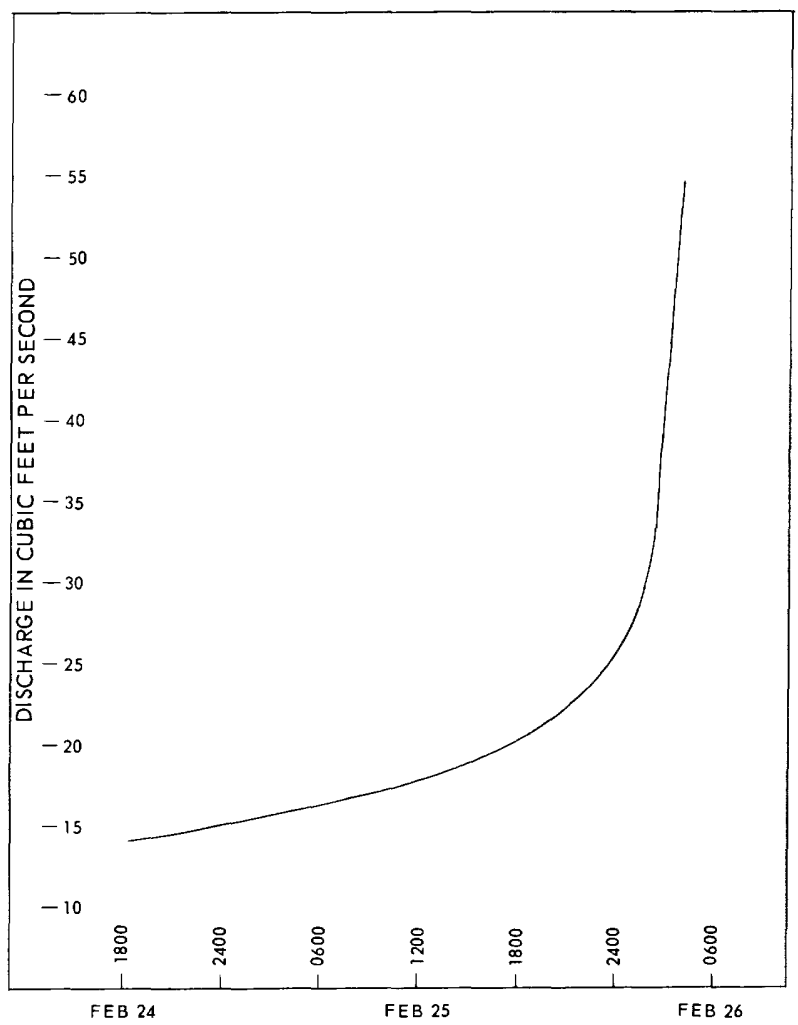

Figure 12.-Inflow to the pool behind coal-waste dam No. 3 from 6:00 p.m. Thursday, February 24, to 4:00 a.m. Saturday, February 26. 
Peak inflow for the storm is estimated as 70 cfs $(31,000 \mathrm{gpm})$ on the basis of yield per square mile determined for several small tributaries in the Buffalo Creek basin near Middle Fork. Data collected at gaging stations on surrounding streams show peaks on February 25 and 26 of nearly the same magnitude; however, the peak discharge on Middle Fork is believed to have occurred on February 26.

\section{FAILURE OF THE DAM}

Apparently there was no eyewitness to the actual failure of dam No. 3, although a number of people were in the vicinity of the dam just before and immediately after the failure. However, the evidence discernible in the remnants of the structure combined with reports of those at the dam before and after its failure serve well to establish the mode and timing of the failure.

GEOLOGIC AND ENGINEERING EVIDENCE

$$
\text { Slumps }
$$

The large volume of water passing through dam No. 3 has removed most of the evidence of slumps. However, a large dome-shaped mound, not eroded or scoured by water action, is at the toe or former front of the dam about 120 feet from the left abutment (figs. 13 and 14). The mound is about 100 feet in diameter and is cut by five tension cracks one-half inch to 1 inch wide and spaced 1 to 22 feet apart. The cracks trend $10^{\circ}$ to $20^{\circ}$ true north azimuth in comparison with the former front of the dam, which trended about $60^{\circ}$. The mound is apparently a remnant of a heave at the toe of a slump that moved diagonally to the left at the front of the dam.

Obvious large slump features are visible in the remnants of both abutments. In general, these slumps are related to the final stage of failure, and the fracture lines related to them are parallel to the abutments.

The sludge that formerly underlaid pool No. 2 has been pushed forward against the back side of dam No. 2. The sludge now forms a series of serrated ridges up to 10 feet high and 20 feet wide separated by elongated depressions up to 20 feet wide. Bedding exposed in the ridges dips gently towards dam No. 3 but is highly contorted. Each ridge is formed of a series of beds of sludge, and the ridge forming units are separated by slippage planes. The sludge was apparently forced against dam No. 2 by slump blocks from dam No. 3, the remains of which are in the back part of pool No. 2.

\section{Subsidence}

The floor of the breach at scour level shows two distinct sump features. Two sump holes, one about 3 feet in diameter and 2 feet deep and the other 6 feet in diameter and $41 / 2$ feet in depth, indicate an outflow of water along the foundation or below it in the sludge base (figs. 13 and 15). These holes contain only coarse material; all the fine material has been removed by subterranean flow.

\section{Foundation Seepage (Piping)}

Within a year prior to the failure of dam No. 3, an employee of the mining company reported sighting black water boiling up from the bottom of pool No. 2. This is indicative of possible extensive seepage through the foundations of dam No. 3.

A large subsidence feature is risible on the left front of the former dam (fo. 16). This sump, about 80 feet in diameter and over 10 feet deep, was occupied by a large pool during the final stages of draining and is now filled with fine material. Both the rim and the outlet of the pool contain coarse, water-washed material, indicating that the pool extends into the foundation to an unknown depth. The pool probably was formed by material being removed in the foundation during failure. This large area of subsidence is opposite the mouth of a small hollow that drained into the haul road at the left abutment. It is possible that water from this hollow entered the side of the dam, causing a large pocket of saturated material which gave rise to a slump and subsidence along the left side of the dam.

Flow Lines

Five distinct levels of flow are discernible on the left abutment (figs. 13 .nd 16). The highest two levels are about 39 feet and 24 feet above the bottom of the breach. They consist of benches about 30 feet wide, sloping $7^{\circ}$ downstream, and ending abruptly at the sump pool near the left abutment where they 

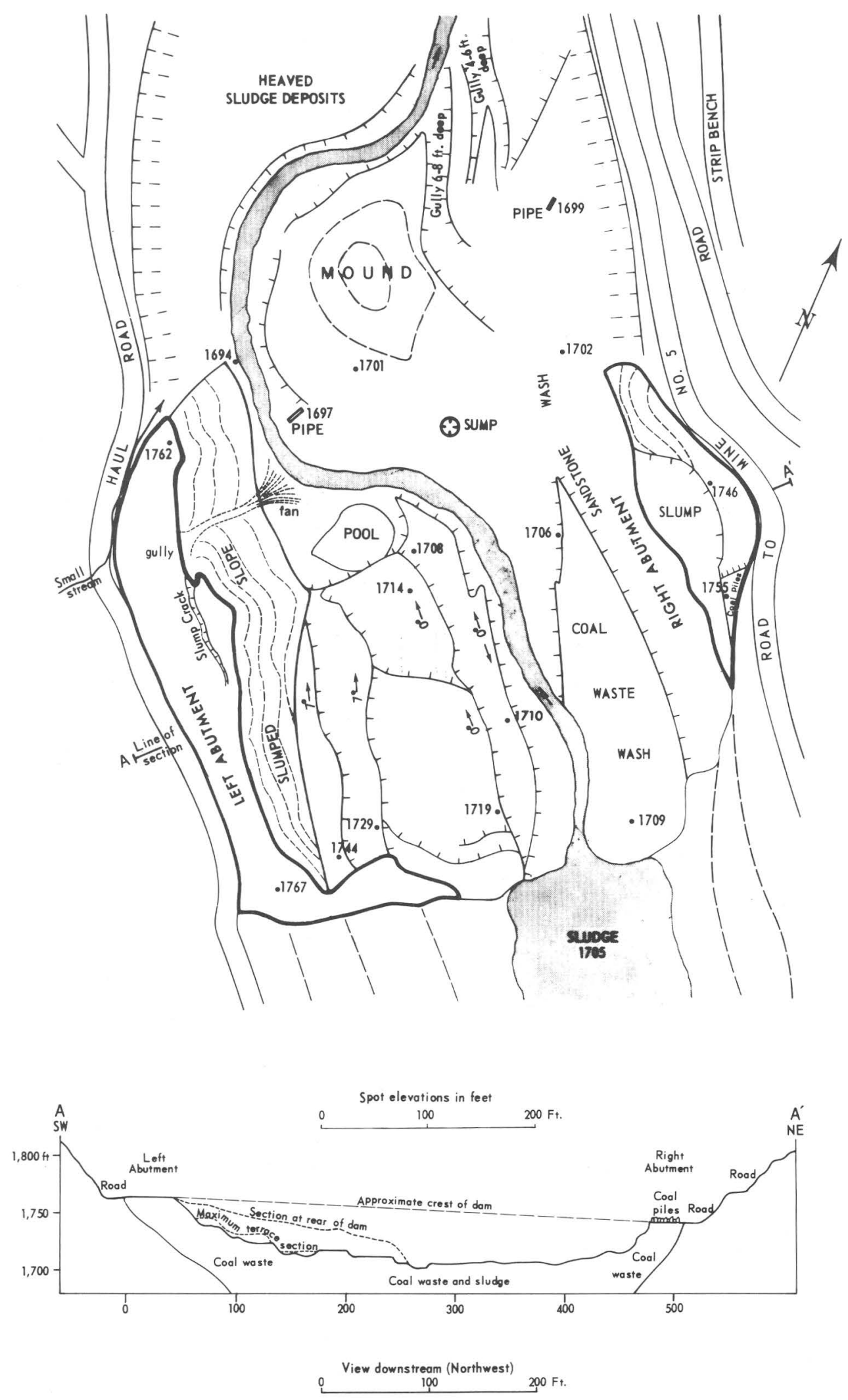

FigURe 13.-Plan and cross-section through coal-waste dam No. 3 after failure, on Middle Fork, Saunders, W. Va. 


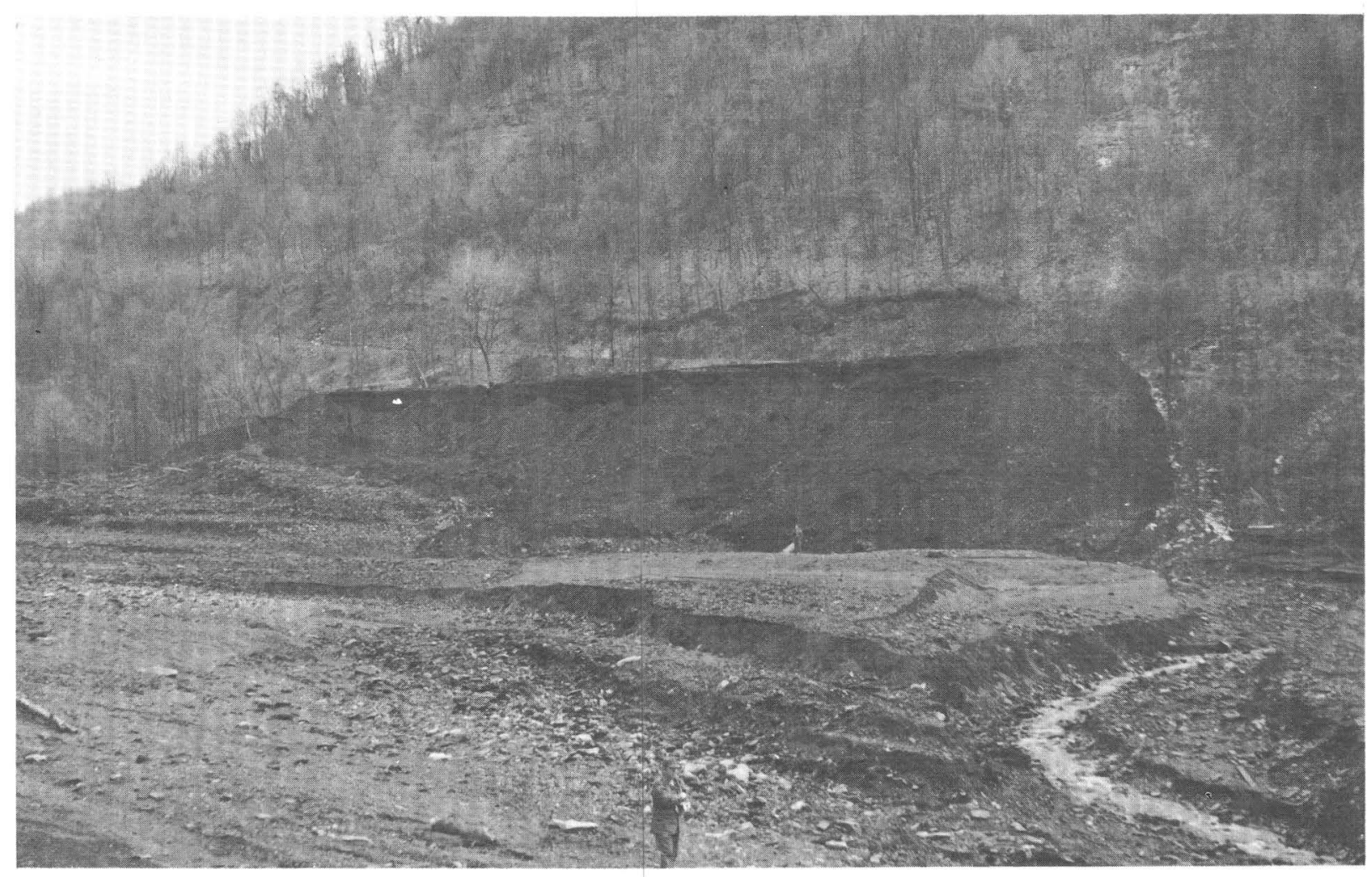

FIGURE 14.-Looking upstream at the left abutment of coal-waste dam No. 3. Unscoured mound in center foreground is apparently a heave at the toe of a slump that moved towards the left front on the dam.

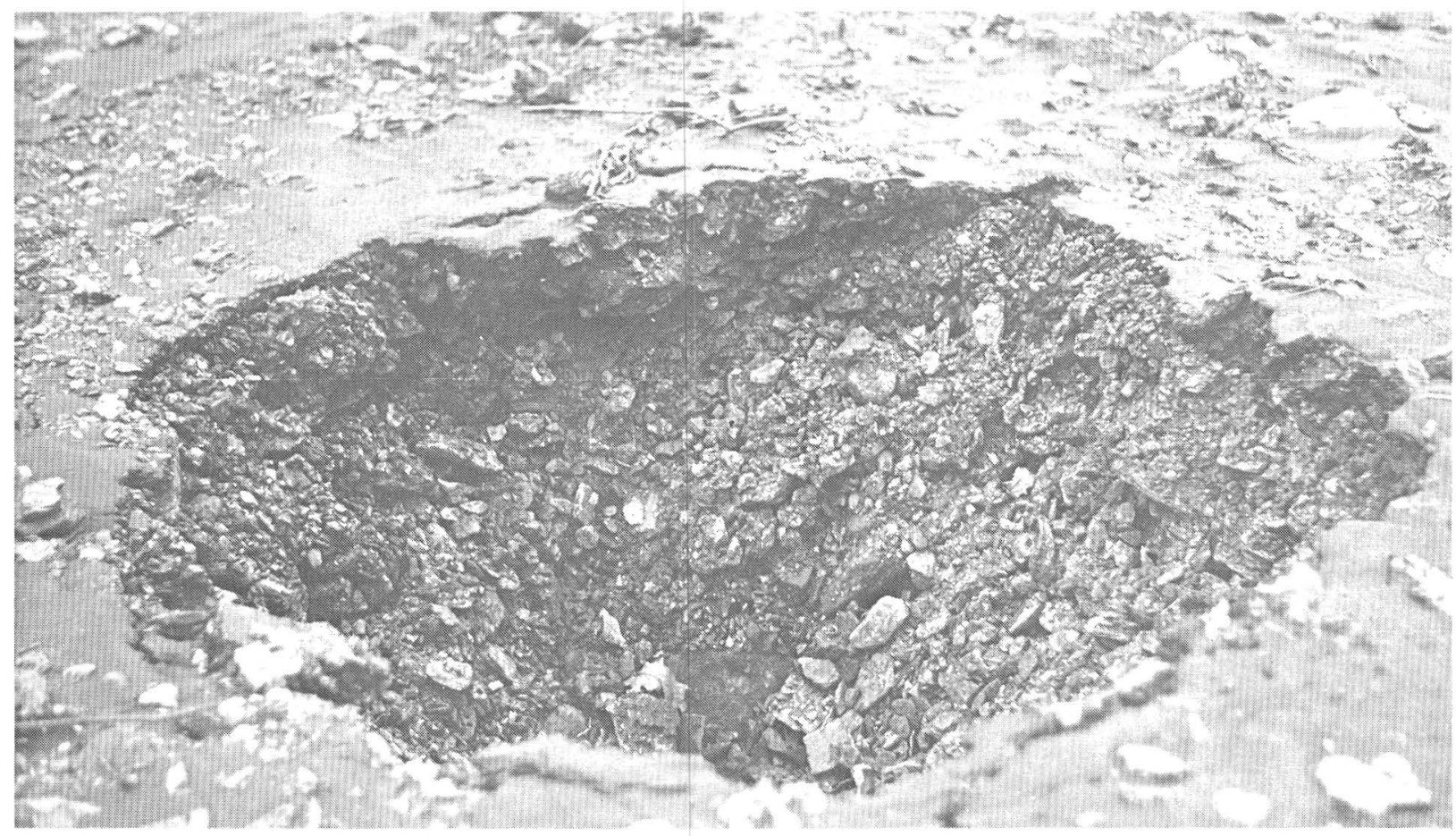

Figure 15.-Sump near former front of coal-waste dam No. 3. Hole is 6 feet in diameter and $4 \frac{1}{2}$ feet deep. 
were cut out by subsequent slumping. The third bench is 14 feet above the lowest flow line, is level, and is cut by an abrupt scarp about 70 feet from the sump pool. The fourth bench is 9 feet above the lowest flow line, is level, and ends in a cut scarp at the sump pool. The fifth bench is broad, covering the right half of the total breach, and is 3 to 5 feet above the lowest flow line. It slopes slightly downstream and is unbroken except by gullies at the lower end.

\section{Debris Lines}

A corridor strewn with slabs of sandstone extends from the valley wall at the rear of the right abutment diagonally across to the large gully at the center of the valley near the site of the front toe of dam No. 3. This sandstone, torn from the wall of the valley, is restricted to a zone 20 to 60 feet wide, is not present elsewhere in the debris from the dam, and is not covered by other debris. This evidence indicates that a strong linear flow persisted on the right side of the dam from the time the pool was at 48 feet until it had been reduced to near 10 feet. Flow through and over the rest of the dam was subordinate to flow through this opening.

\section{EYEWITNESS OBSERVATIONS}

Between 6:00 and 6:30 a.m. Saturday, one witness drove up from Saunders to check the water level behind the dam. "The dam was moving like a bridge moves under heavy traffic. Water was coming through the dam at $6: 30$ a.m.--not much, but it was causing the lower lake to fill up fast. This water had cut the road below the dam [at dam No. 2], and they had a front-end loader trying to ditch the road." He also reported that dam No. 3 had sunk in some spots on the right side and that there were surface cracks running parallel with the face of the dam.

Another witness was checking the dam between 7:30 a.m. and 8:00 a.m. The water was coming up between the piles of slate (coal waste) that trucks had dumped. "I could see it coming into the holes on top of the dam. The top of the dam was moving back and forth-I could see that the front of the dam had broken off and was sliding in on the lower side. The dam was settling down and it was shoving forward. About 20 feet of the face had broken or slid off during the night." According to this witness, "It was like walking in soup, it had done gotten real juicy, buddy, all the way down. I got in the car and got the hell outta there." $\mathrm{He}$ reported sinking to his ankles in the saturated material on the graded crest of the dam.

Witnesses indicated the dam had a history of instability; it had slumped in the past and slate had been dumped to fill the low places. This was a recurring condition but was not considered to be dangerous; the water had never before been as high as it was on February 26, 1972 . The 24 -inch drain pipe placed a few feet below the top of the dam was "running full" but was inadequate for the heavy runoff of the last few days.

Another witness who was at dam No. $3 \mathrm{im}$ mediately after the failure indicates that water was pouring out and cutting away the dam from the right side. Then a larger portion of the dam broke loose toward the center. This break sent a mass of water and sludge onto the burning coal-waste bank No. 1, which brought on an explosion.

At the time of the failure, another witness was on his way home from the "Hoot Owl" shift. It was about 7:56 a.m. Saturday morning. He was driving down the right side of the valley on the lower road above the reservoir behind dam No. 3. He had just made the last small curve and turned down the slope about 300 feet above the back side of the dam when his car was suddenly showered with black water containing fine black material. "My windshield and car were completely covered with black sludge-I knew she [the dam] had gone out! I looked and saw the road was gone and things were kicking up. I looked down the valley and saw the truck shop toss up and over and I saw a Dart [truck] go up and over. Then I turned around and went back to No. 5 mine to warn the people in the valley below. The phone was out."

A person staying with friends in a twostory frame house 600 feet up Buffalo Creek from the burning waste bank reported that ashes and coal dust blew down upon them as they came out of the back of the house to run 


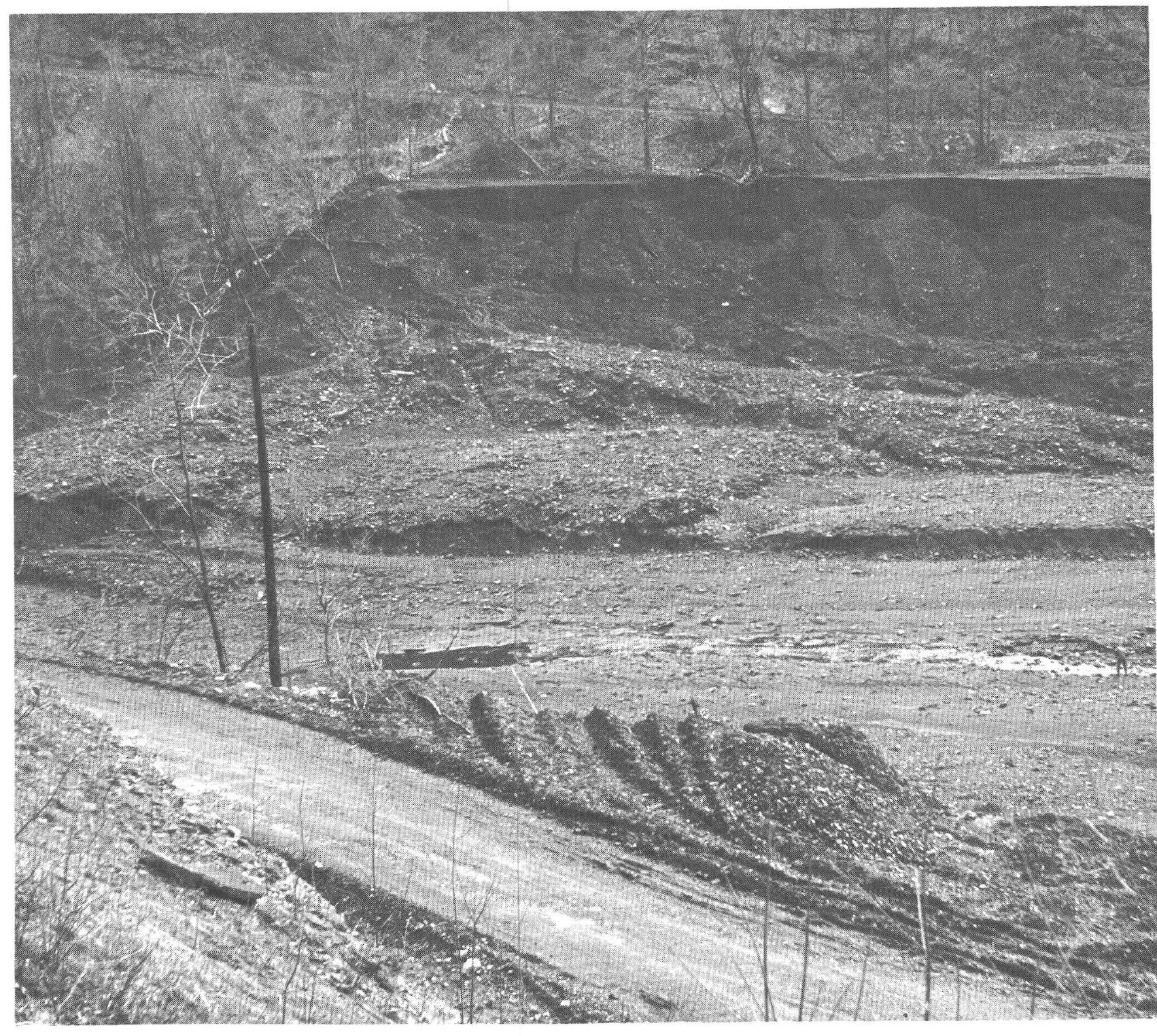

Figure 16.-View across coal-waste dam No. 3 from right abutment.

up the hill after the burning bank blew up.

A Saunders resident reported his electric power went out at 8:00 a.m. and shortly after, water came out of the lower waste bank and into the valley. He sent his family up the hill and he went down to move his car; however, the water came up too fast and he was forced to run back across the railroad track and up the hill. He turned and saw his house floating off its foundation. At about this time he saw the burning waste bank blow up. "The explosion looked like an atomic bomb and shook the ground." Shortly thereafter the big crest of water and sludge flowed out into the valley. "The wall of sludge and water was boiling up like dry flour when you pour water on it."

Several eyewitnesses indicated that company employees planned to place 24-inch metal pipes, which were on hand at the dam, to drain water from the crest of the right side of the dam to the diversion ditch along the haul road. However, before a bulldozer could be brought in to aid in entrenching the pipe, the dam had failed.

Wash from a small hollow was stated to be blocking the haul road and diversion ditch 
After 4:30 a.m., February 26, conditions within dam No. 3 were such that failure was well underway. The phreatic surface (the top of the water-saturated material in the dam) had been driven forward until its upper surface was near or at the crest of the dam in the rear half of the structure. With increased head, the phreatic surface rapidly expanded and its front slope increased, probably to $6: 1$ or $7: 1$, and the margin of safety approached zero. The increase in head of the pool and in pore pressures during the preceding 24 hours had caused heaves, blowouts, and slumps in the front of dam No. 3. Between 12:30 a.m. and $6: 30$ a.m., increased saturation and pore pressure probably caused some swelling, uplift, and undulation of the surface of the dam. By 6:30 a.m., the pressure was probably reduced by fracture and upheaval of the dam as indicated by eyewitness accounts concerning the undulation of the surface of the dam and its soupy condition. Within the next hour, extensive slumping and subsidence apparently set in, causing some lowering of the crest of the dam.

At $6: 30$ a.m., February 26, water was seeping through the coal piles at the rear of the crest adding to the saturation of the upper layers of the dam. Several large subsidence holes had developed on the crest. Some of the water from this upper saturated zone drained across the right abutment along bulldozer tracks and flowed around the dam and down the haul road. In one rut, this flow was up to 14 inches wide and 11/2 inches deep (fig. 17). Four other tracks within 20 feet of each other show somewhat smaller flow.

By 6:30 a.m., February 26, seepage through the dam and discharge from the overflow pipe had filled the pond behind dam No. 2 to near its crest. Water was also cascading onto dam No. 2 from a small hollow on the northeast and from water on the haul road. Wash from the hollow had blocked the road at dam No. 2 until the water was diverted past dam No. 2 by ditching and bulldozing an embankment

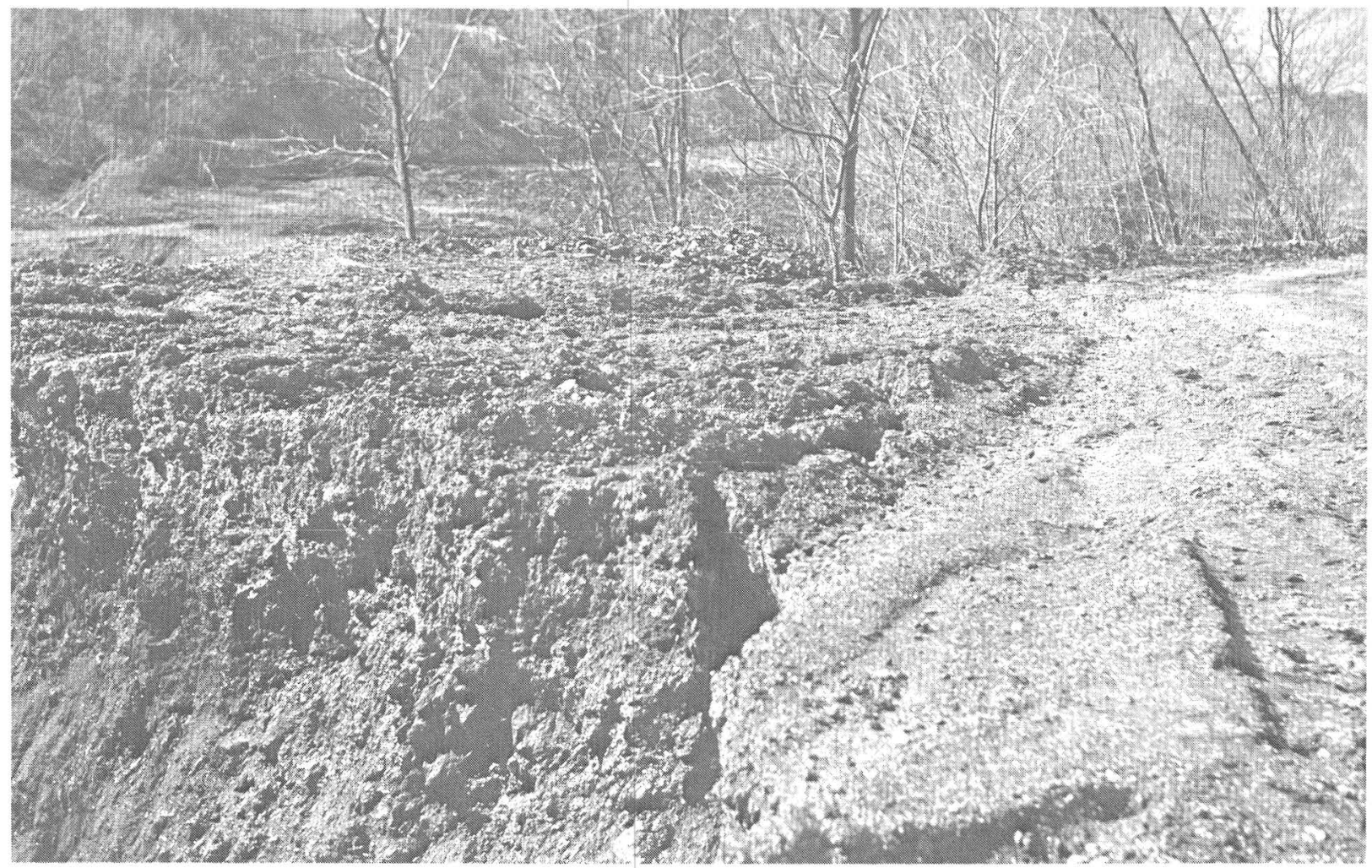

FIGURE 17.-Top of right abutment of coal-waste dam No. 3 showing 14-inch-wide water channel developed along bulldozer tracks. 
along the road. Reports, however, indicate that increased flow from the gradual failure of dam No. 3 upstream caused overtopping and breaching of dam No. 2 after $7: 30$ a.m. and before the total failure of dam No. 3. The water released from dam No. 2 caused a sudden rise in Buffalo Creek.

After 7:30 a.m., the top of dam No. 3 was cut by cracks extending from abutment to abutment parallel to the faces. Water was rising to the crest through these fractures and other holes. The front of the dam was sliding off and the crest was lowering noticeably. Apparently by this time pore pressure had passed the maximum, the flow line within the bank was near the crest, and the entire right side of the dam was buoyant and was being driven to the downstream face. The pore pressure was further relieved by internal slippage and slumping that finally produced total failure through overtopping of the slumped blocks.

Total failure occurred about 7:59 a.m. when the right side of the dam breached along a line starting about 120 feet from the front of the right abutment and trending diagonally towards the valley wall at the rear. Extreme turbulence threw coal-laden water 300 feet from the dam and splattered cars on the haul road. Within seconds, dam No. 2 was topped on both the right and left sides, the existing breach on its right abutment was enlarged, and the sludge behind was thrown into great convolutions by the slump blocks (fig. 18). The sludge ridges raised by these blocks protected the center part of dam No. 2 from overtopping and breaching. The clear pool was filled, overtopped, and the small dike on its right side breached (fig. 19), and the shed and transformer pole was destroyed at 8:00 a.m. Water pouring through the breach in dam No. 2 rebounded from the sandstone wall and scoured the left side of the clear pond (No. 1) cutting away most of dam No. 2 and leaving steep undercut banks.

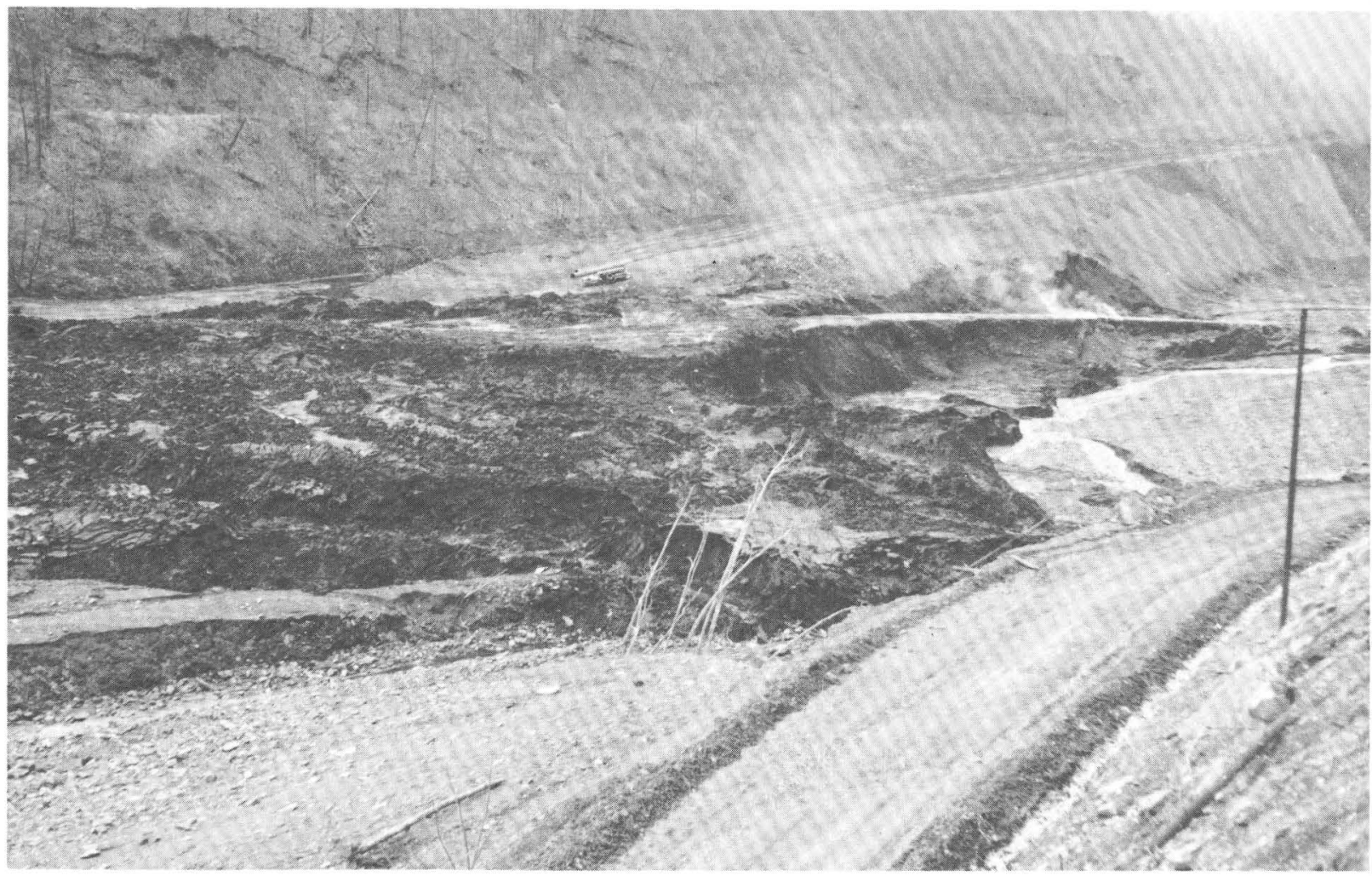

Figure 18.-Breach in coal-waste dam No. 2. Most of orignal dam was washed away; parallel ridges of sludge behind dam No. 2 were pushed against the dam by slump blocks during the failure of dam No. 3 . 


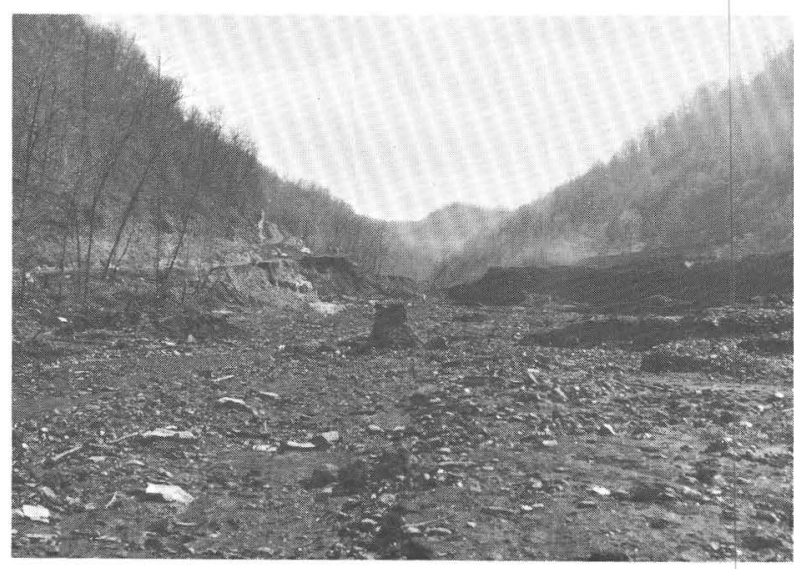

Figure 19.-View upstream across former clear pond behind coal-waste bank No. 1. Remnants of coalwaste dam No. 2 are visible in the middle ground.

The torrent of water crossed the haul road at the south end of the burning coal-waste bank No. 1, but the compacted road bed was only slightly eroded (fig. 20). At the lower end of the burning coal-waste bank, the water increased the hydrostatic pressure within the bank, causing explosions of steam and producer-type gas. The three or four explosions reported were severe enough to shake the ground at Saunders and raise mushroomshaped clouds of ash and smoke. Moments later, at about 8:01 a.m., the torrent of water en-

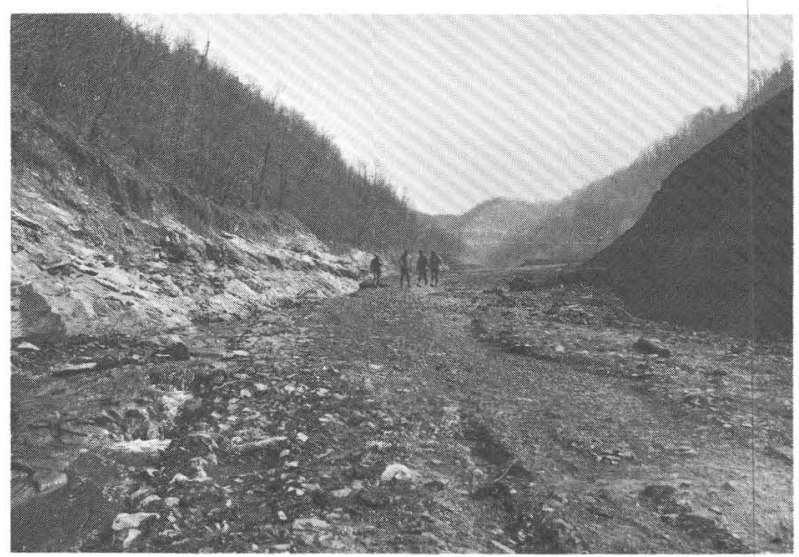

Figure 20.-Haul road looking upstream midway along the right edge of coal-waste bank No. 1. The haul road served as the initial water gap around the upstream edge of bank No. 1. Height of floodwater is shown by bedrock scar on left; haul road itself suffered only slight erosion at this point. tered Buffalo Creek. The cascading torrent followed an existing depression within the coal-waste bank at the front, which curved abruptly to the west. This abrupt curve diverted part of the initial surge towards the church at the mouth of Lee Fork.

Another part of the flow followed the haul road as far as 100 feet east of the curve at the mouth of the hollow, trenching the road to a depth of 4 feet, cascading over the slope to Buffalo Creek, and carrying away much of the soil. The barrier that formed the abrupt curve at the mouth of the hollow was quickly demolished, and immediately a surge crossed the valley of Buffalo Creek and rose 37 feet up the north wall of the valley. This sudden rise was dissipated within 400 feet downstream and 100 feet upstream. Backwater with fine debris flowed about 500 feet east into Buffalo Creek above Middle Fork. After the initial surge, the flow into Buffalo Creek was relatively uniform, controlled by the breach in dam No. 2 and the constriction between coalwaste bank No. 1 and the valley wall along the haul road. In the area of explosions, the torrent cut through the haul road forming a canyon 40-50 feet deep, 700 feet long, up to 30 feet wide at the bottom (figs. 21 and 22).

Meanwhile, at dam No. 3, the torrent from the initial linear failure was great enough to tear sandstone from the valley walls along the rear of the right abutment (fig. 23). The failure spread across the dam to the left side and large slump blocks were carried away at the center of the dam, almost simultaneously as the initial linear failure developed.

Moments after the linear failure developed, a large subsidence and slump apparently occurred in the front half of the dam near the left abutment. Slumps from this failure rapidly extended across the front of the dam connecting with those in the center. The overflow pipe was carried away in these failures; the lower (front) end came to rest below the right abutment and upper (rear) end moved across the site of the dam, ending up near the front left abutment (fig. 13).

By the time the pool had been reduced by about 9 feet to the 39 -foot level, the water was flowing across all but approximately 50 feet of the left abutment, and the water-surface 


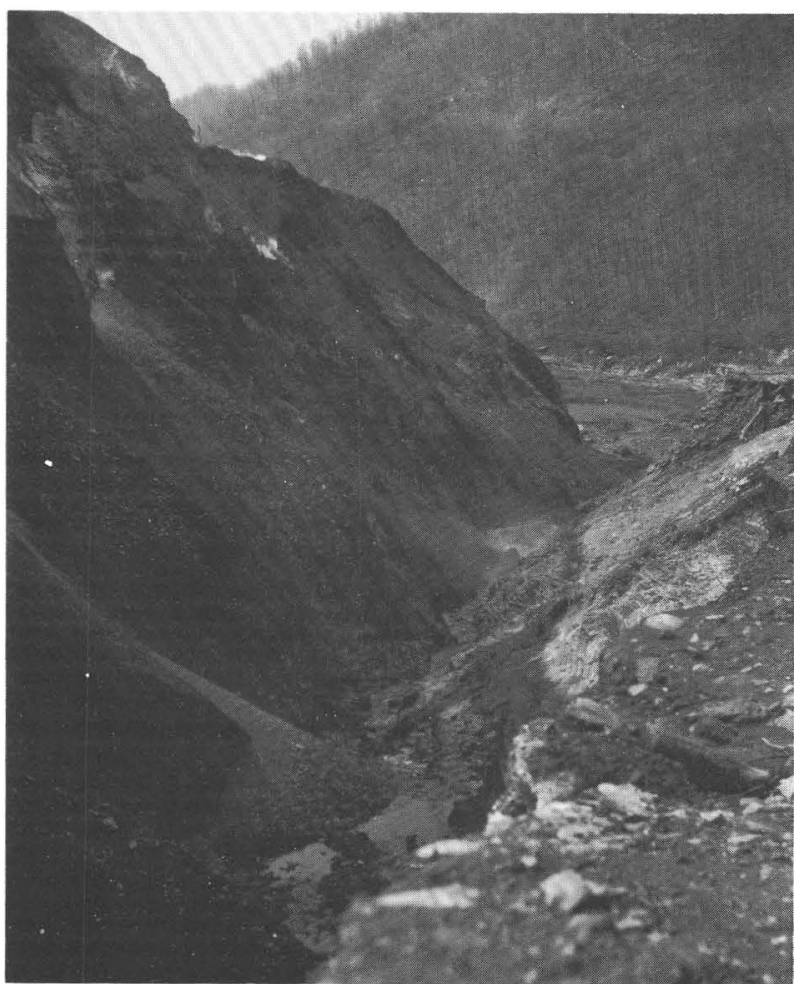

Figure 21.-View down the canyon cut along the right side of coal-waste bank No. 1 at the mouth of Middle Fork.

gradient, as indicated by the slope of the water planed area at the base of the flow, was about $7^{\circ}$ (figs. 13 and 16). A similar gradient existed when the top of the pool was at a level of 24 feet above the bottom. When the pool was reduced to the 14 -foot level, flow extended from the right bank to a point about twothirds of the way to the left bank at a nearly level gradient. At this time the narrow defile along the haul road at coal-waste bank No. 1 and the breach on the right and the channel on the left side of dam No. 2 were apparently acting as controls, and a large sheet of water up to 30 feet deep was backed up retarding flow through the breach in dam No. 3.

Flow along the center and right continued until the pool was reduced to a 5-foot level and the water gradient was level. The final discharge from the pool began at the center but was diverted to the left abutment by further slump and subsidence along the left front and by a heave that had occurred at the toe of the lower face near the center (figs. 14 and

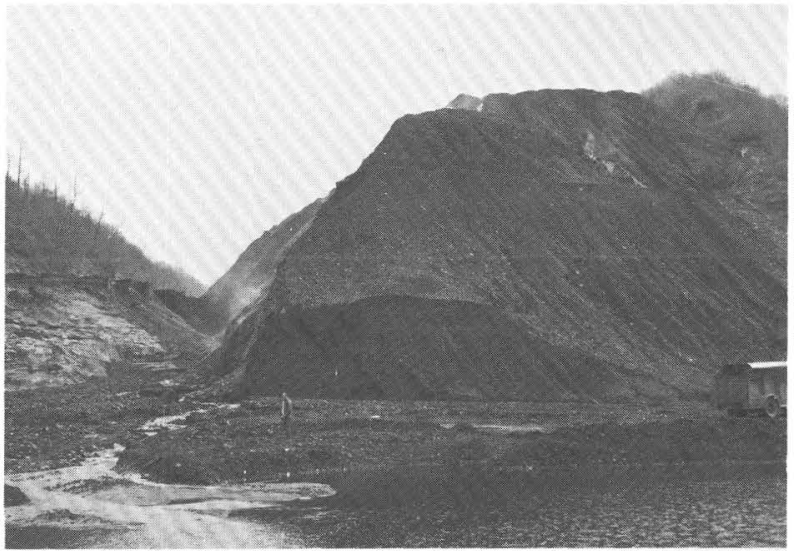

FIGURE 22.-Face of coal-waste bank No. 1 at the intersection of Middle Fork and Buffalo Creek. Canyon was eroded in area of explosions on the left.

16). This final discharge was small and was ponded in the subsidence area for some time before passing through the slump.

After the impoundment drained (fig. 25), a small stream continued to flow across the center of the rear of the site of the dam and swung to the left abutment along the line of the final drainage route of the pool (figs. 16 and 24). The time needed to discharge most of the volume of impounded water through the breached dam was on the order of 15 minutes or less; most of the water in the pool above the height of $\mathbf{1 5}$ feet poured out within the first few minutes. Drainage of the pool at a greatly reduced rate continued until about $8: 30$ a.m.

About 6 million cubic feet of coal waste and other debris was carried downstream from the breach at dam No. 3 (figs. $26 A$ and $26 B$ ). Some of this debris was deposited as slumps in pool No. 2 in front of dam No. 3. Practically none was left in the clear pool, and over 90 percent of the debris was carried into Buffalo Creek valley and deposited as far downstream as Pardee, 2 miles below Middle Fork (fig. 27).

A brief but very heavy rainfall apparently occurred in the vicinity of Lee Fork, within 30 minutes after dam No. 3 broke. As a result of this rainfall, two debris avalanches, one involving some 225,000 cubic feet and the other some 30,000 cubic feet of debris, descended into Buffalo Creek from hollows just to the 


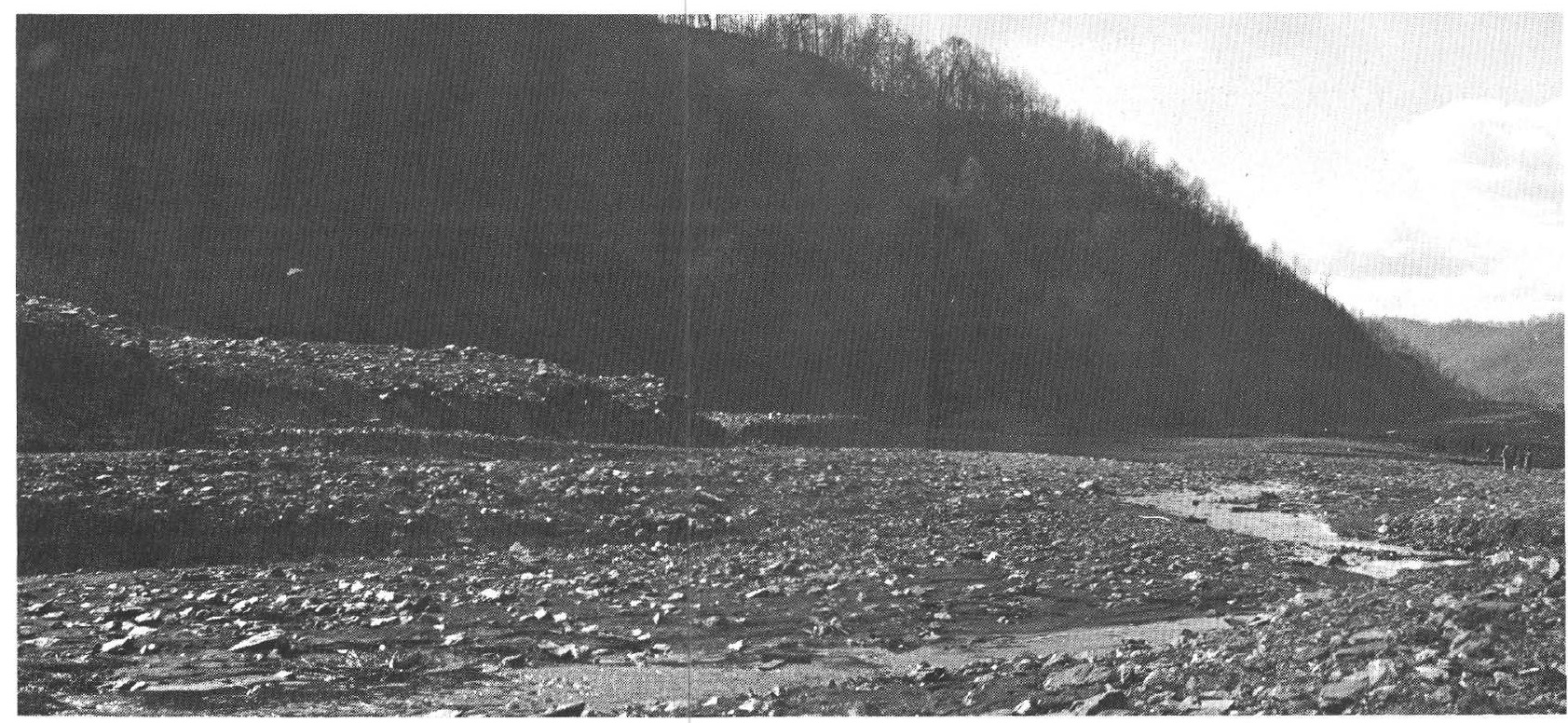

FIGURE 23.-Panorama view downstream through the breach in coal-waste dam No. 3. Initial linear breach extended into valley wall on right, ripping out sandstone.

west of Middle Fork; the debris fans formed at the bases of the hollows were not altered by flow down Buffalo Creek and therefore must have occurred after the main flood. A small side hollow on the left side of Middle Fork at dam No. 3 cascaded a large quantity of water over the remnant of the left abutment, cutting a large gully in the slumped slopes (figs. 13 and 16).

\section{ANALYSIS OF OTHER REPORTED MODES OF FAILURE}

Several other causes of the failure of coalwaste dam No. 3 have been cited elsewhere, but eyewitness accounts and geological-engineering evidence refute them. The causes cited and refuted are explosions within the dam, ditching, and dynamiting.

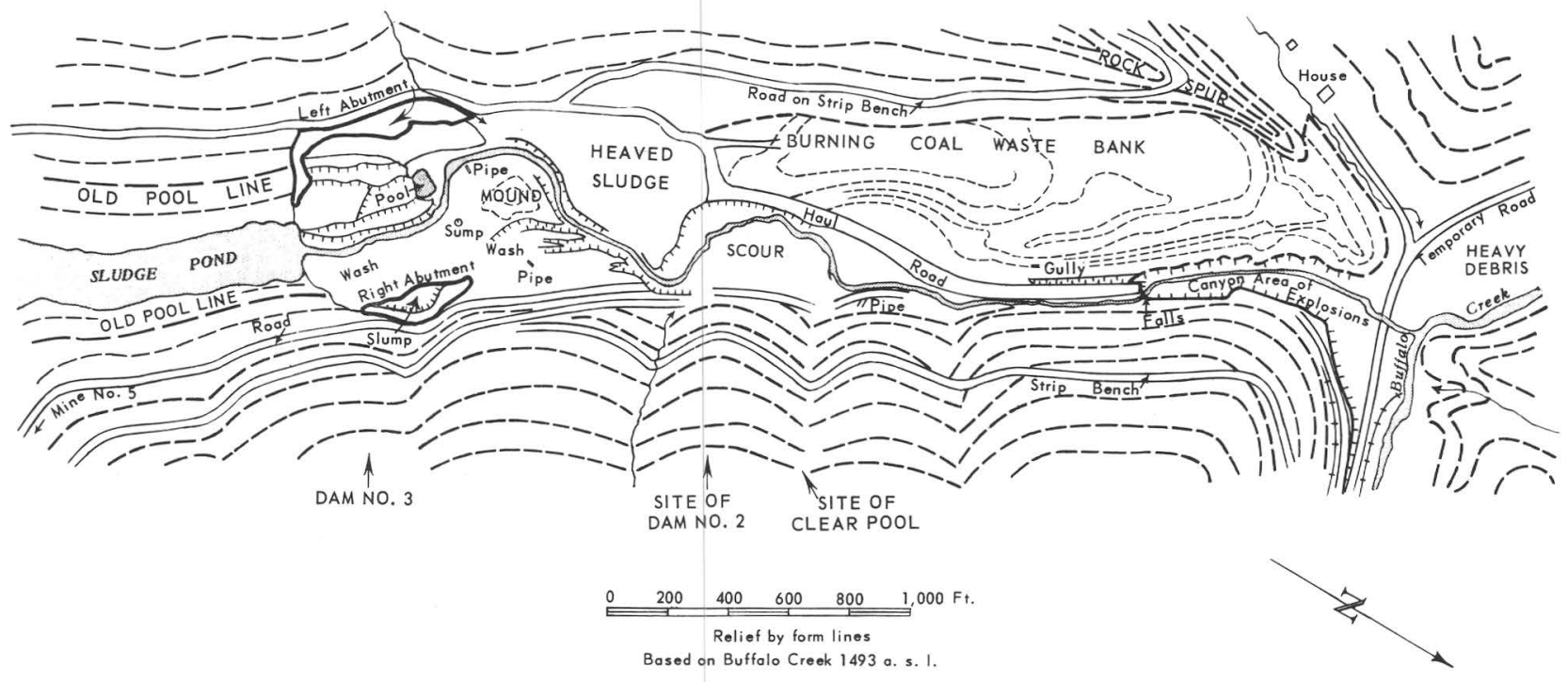

Figure 24.-Sketch map of Middle Fork on February 26, 1972, shortly after dam failure. 


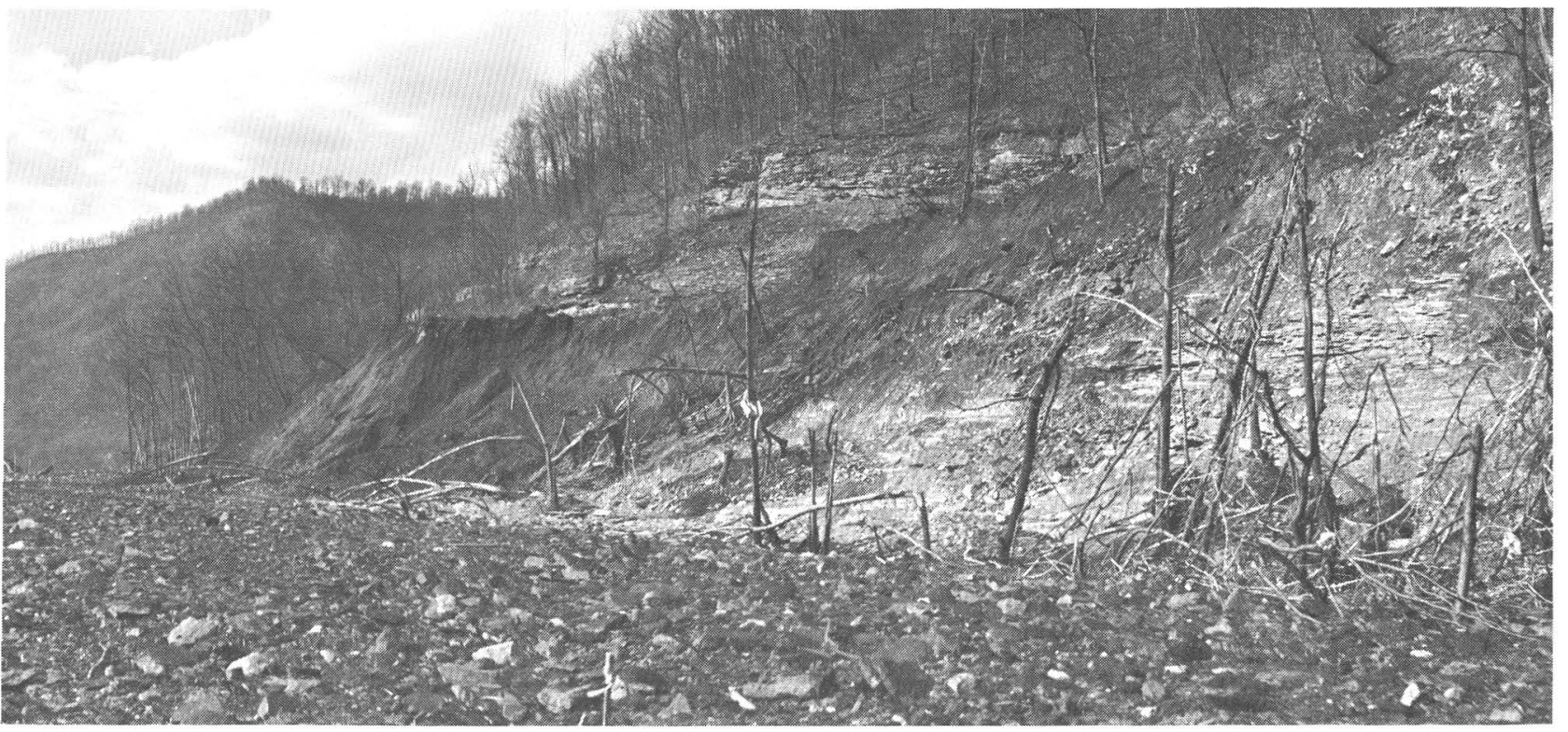

Explosions Within the Dam

The remnants of the dam show no evidence of combustion. No red dog (the common byproduct of burning coal waste) except that derived from wash from the haul road is in or directly below the remains of dam No. 3. No part of the remains of dam No. 3 was burning immediately after the flood. "Smoke" reported issuing from the dam at the time of failure was probably warm moist air driven from the fractures by increasing hydraulic pressure. The explosion that occurred immediately following the failure was in the burning coal-

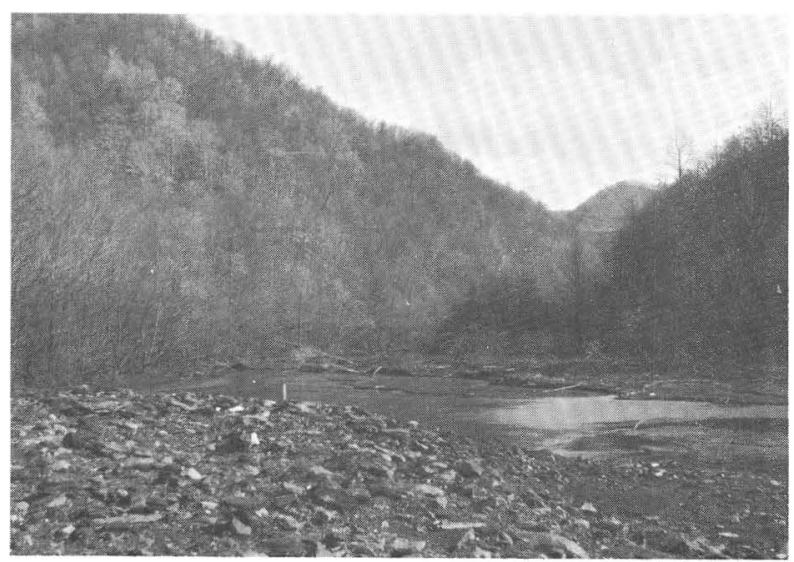

Figure 25.-Pool area above coal-waste dam No. 3 following failure of the dam. Floor is saturated sludge. waste bank No. 1 at the mouth of the hollow, about 2,600 feet downstream from dam No. 3 .

\section{Ditching}

A witness reported that a company official had checked conditions at the dam the morning of the failure. The witness was informed by the official that "he was ditching around the dam and it was safe." Field evidence and eyewitness reports indicate the ditching was done on the haul road at the right abutment of dam No. 2, which is located below the dam (No. 3) that actually failed and released the floodwater. This ditching and mounding were done by a front-end loader to divert water from a side hollow and the haul road around dam No. 2. There is no conclusive evidence that alteration at the surface of dam No. 3 was made by ditching or scraping, either during or immediately before the failure of dam No. 3.

\section{Dynamiting}

A press story attributed the failure of the dam to company personnel dynamiting the top of the dam in an attempt to drain off the pool. Evidence cited included blasting wire and drill holes at the site. All wire seen at the site was telephone wire or used waste-blasting wire deposited in the banks along with other refuse from mines. The drill holes were in sandstone 


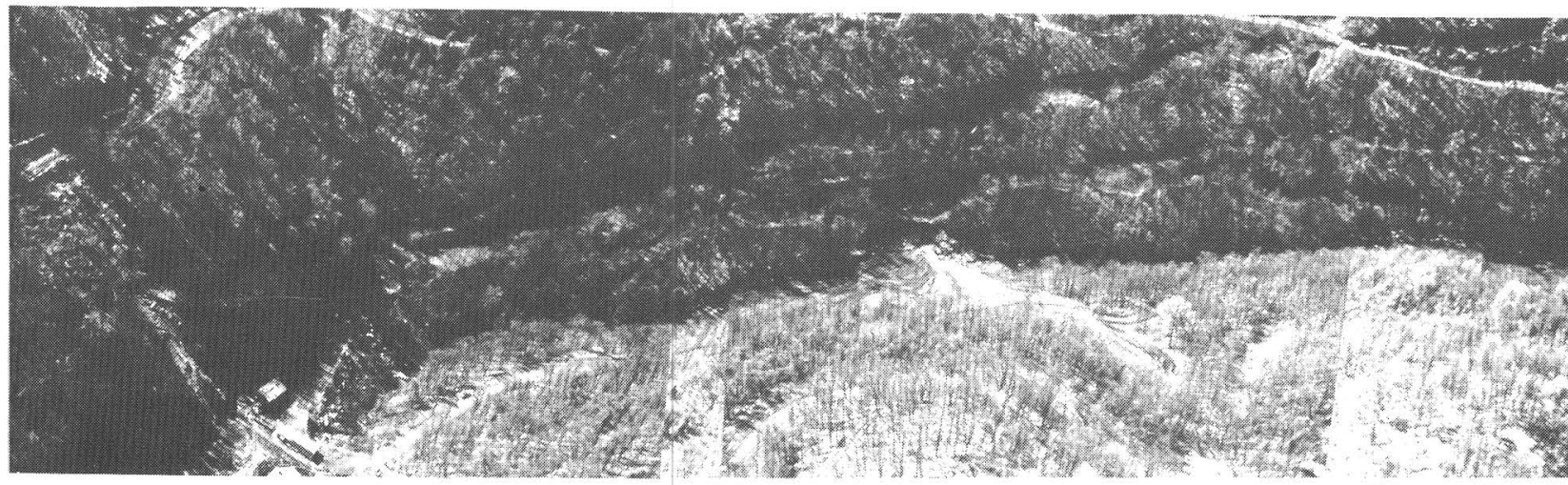

Figure 26.-Middle Fork, panoramic view $(A)$, mine N $\mathrm{c} .5$ to Buffalo Creek, March 5, 1972. Vertical aerial photograph $(B)$, dam No. 3 to Buffalo Creek, February 28, 1972.

and were remnants of blasting operations during construction of the haul road several years ago.

Television pictures of the reported site of dynamiting were made at the canyon cut in coal-waste bank No. 1 and were about 2,600 feet downstream from the site of the actual dam failure at coal-waste dam No. 3. Wire at this point shown in the television film is telephone wire; blasting holes were those related to building the haul road.

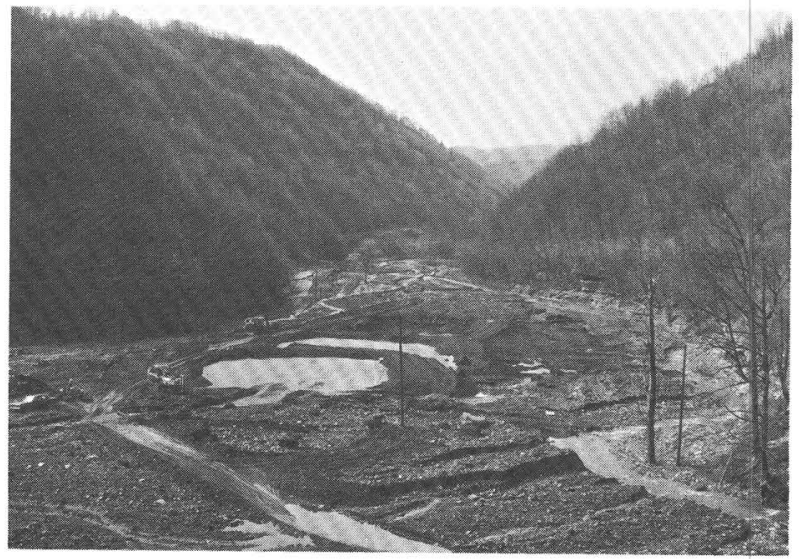

Figure 27.-Debris from Middle Fork deposited in Buffalo Creek, looking downstream over former site of Saunders. Middle Fork enters to the left of the photograph.

\section{CONCLUSIONS AS TO CAUSE OF DAM FAILURE}

Five causes led to the failure of coal-waste dam No. 3 :

1. The dam was not designed or constructed to withstand the potential head of water that could be impounded. It was primarily a waste pile that grew from routine dumping of waste.

2. Spillway and other adequate water-level controls were not in the dam, and no provision had been made for removing water once it had entered the pool behind the dam. The capacity of the 24-inch pipe was too small to handle large flows, and the pipe was placed so high that water rising to it greatly increased instability of the dam.

3. The sludge on which the dam was placed was inadequate as a foundation. Seepage through the foundation gave rise to extensive removal of material (piping). The weak foundations also gave rise to extensive slumps and subsidence which led to the initial breach and overtopping.

4. The great thickness of the dam (from front to back) in relation to height without engineered compaction led to a decrease rather than an increase in the stability of the dam. The thickness, along with some relatively small compaction, impeded seepage through the bank and thus produced a higher phreatic surface. The high phreatic surface was reflected in sat- 


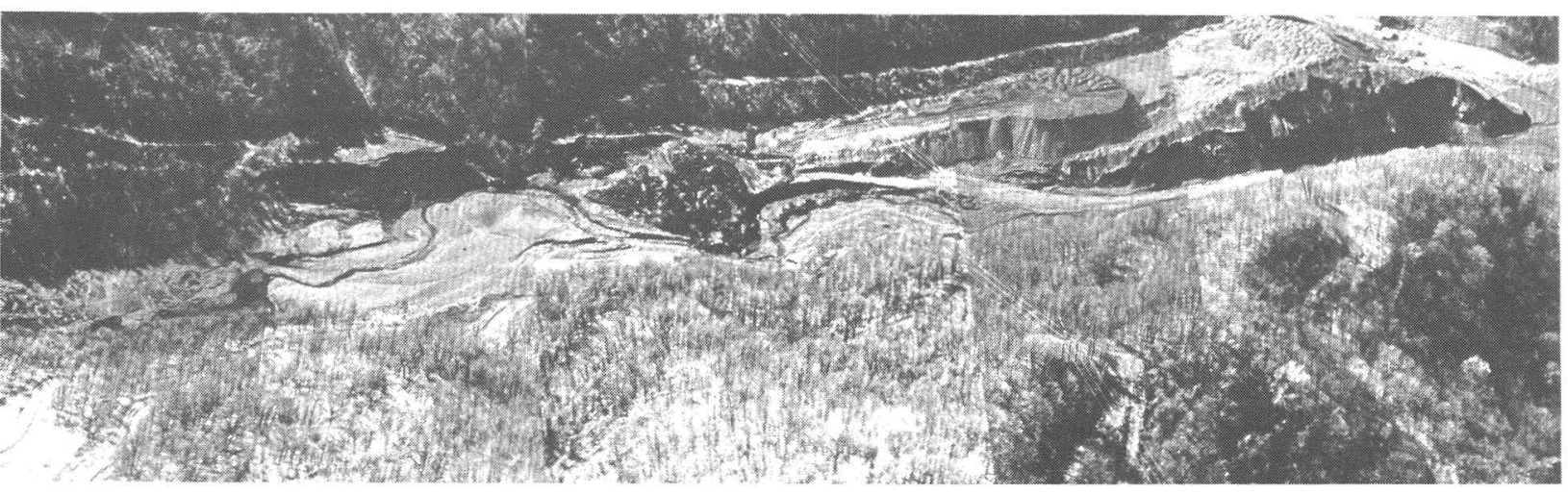

0

600 $1200 \mathrm{ft}$

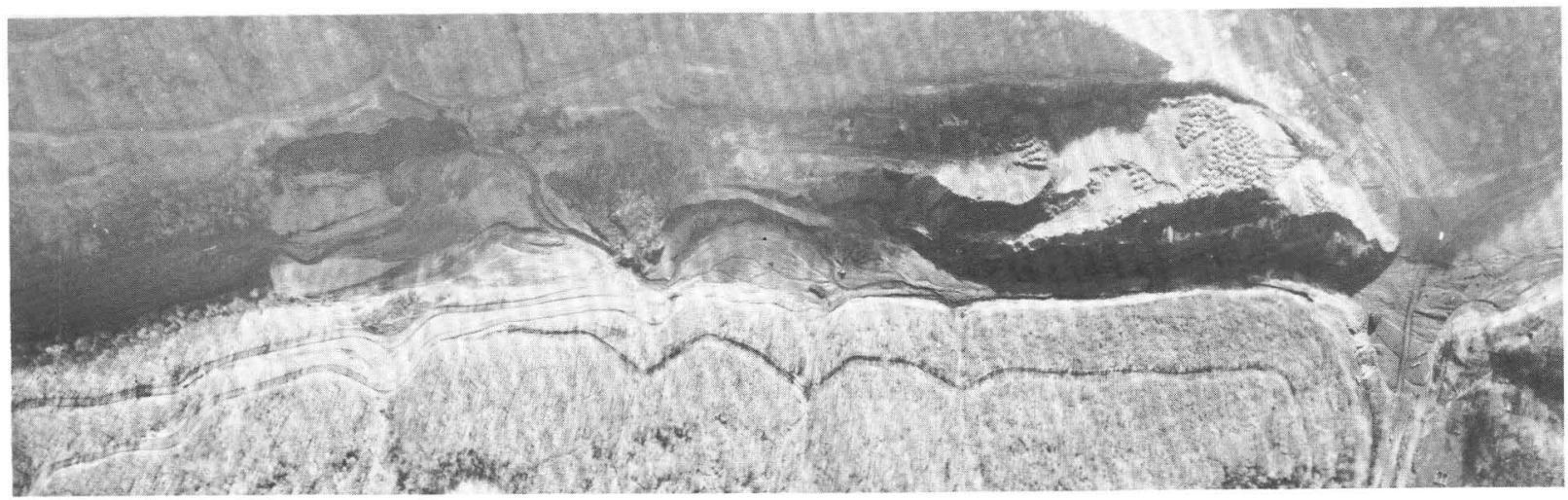

$B$

uration of the dam and the resulting buoyancy accelerated the failure. The impediments to internal drainage also limited the effectiveness of seepage in regulating the height of the impoundment.

5. The dam was constructed of coal waste, including fine coal, shale, clay, and mine rubbish. This material disintegrates rapidly, is high in soluble sulfates which reduce bonding strength, is noncohesive, and does not compact uniformly. A safe, economical dam could not be constructed from such material alone.

The full contribution of the pipe to the failure of dam No. 3 cannot be established from evidence now available, but the fill found in the pipe opens to question the effectiveness of the pipe as a drain control, and the lack of a collar and baffles greatly increased the chance of seepage being carried along the outside of the pipe deep into the dam.

\section{THE FLOOD}

FLOOD CONDITIONS IN THE GUYANDOTTE RIVER BASIN

Precipitation occurring February 24-26 in the southwestern corner of West Virginia resulted in slightly higher than bankfull stages for most streams and in flows generally bearing recurrence intervals of 10 years or less. Peak flows for the storm of February 24-26, 1972, were not unusually high, except for sites on Buffalo Creek below the mouth of Middle Fork (table 3).

The gaging station on the Guyandotte River at Man, located 500 feet upstream from the mouth of Buffalo Creek, recorded peak stages of 18.65 feet on February 25 and 19.34 and 19.02 feet on February 26. The peak discharge for February 25 was 29,600 cfs (13 million gallons per minute), an 8-year flood. The peak stage of 19.34 feet was a direct result of inflow from Buffalo Creek following the failure 
TABLE 3.-Floods in southwestern West Virginia, February 25-27, 1972

\begin{tabular}{|c|c|c|c|c|c|c|c|c|c|c|c|}
\hline \multirow{3}{*}{$\begin{array}{l}\text { Sertion } \\
\text { Number }\end{array}$} & \multirow{3}{*}{$\begin{array}{l}\text { State Name } \\
\text { and Location }\end{array}$} & \multirow{3}{*}{$\begin{array}{l}\text { Period of } \\
\text { Record }\end{array}$} & \multirow{3}{*}{$\begin{array}{l}\text { Drainoge } \\
\text { oreo } \\
\text { (Sq Mi) }\end{array}$} & \multicolumn{8}{|c|}{ Discharge Date } \\
\hline & & & & \multicolumn{4}{|c|}{ Moximum Fleods of Record } & \multicolumn{4}{|c|}{ February 1972 Flood (Preliminary) } \\
\hline & & & & Dote & $\underset{(t+)^{-}}{\text {G. Ht. }}$ & $\begin{array}{c}\text { Discharge } \\
\text { efs }\end{array}$ & $\begin{array}{l}\text { Recurrence } \\
\text { interval } \\
\text { (yeors) }\end{array}$ & Dote & G. $\mathrm{Ht}_{\mathrm{t} t}$ & $\begin{array}{l}\text { Discharge } \\
\text { ofs }\end{array}$ & $\begin{array}{l}\text { Recurrence } \\
\text { interval } \\
\text { (years) }\end{array}$ \\
\hline 1965 & $\begin{array}{l}\text { Big Coal River } \\
\text { at Ashtord }\end{array}$ & $\begin{array}{l}1908-16 \\
1930-71\end{array}$ & 393 & $8-9-16$ & 36.3 & 35,800 & $>50$ & $2-26-72$ & 23.28 & 20,600 & 18 \\
\hline 1990 & $\begin{array}{l}\text { Litrle Cool River } \\
\text { at Donville }\end{array}$ & $1930-71$ & 270 & $2-3-39$ & 30.2 & 42,800 & $>50$ & $2-26-72$ & 21.45 & 14,300 & 9 \\
\hline 2024 & $\begin{array}{l}\text { Guyandotte River } \\
\text { of Baileyville }\end{array}$ & $1968-71$ & 208 & $12-31-69$ & 16.22 & 16,300 & & $2-26-72$ & 17.25 & 18,500 & \\
\hline \multirow[t]{2}{*}{2024.80} & \multirow{2}{*}{$\begin{array}{l}\text { Brior Creek of } \\
\text { Fonrock }\end{array}$} & \multirow[t]{2}{*}{$1969-71$} & \multirow[t]{2}{*}{7.20} & \multirow[t]{2}{*}{$12-30-69$} & \multirow[t]{2}{*}{5.46} & \multirow[t]{2}{*}{485} & & $2-24-72$ & 5.57 & 512 & \\
\hline & & & & & & & & $2 \cdot 26-72$ & 5.21 & 422 & \\
\hline b/ (1) & $\begin{array}{l}\text { North Fork obove } \\
\text { Middle Fork }\end{array}$ & & 0.85 & & & & & $2-26-72$ & & 80 & 2 \\
\hline b/ (2) & $\begin{array}{l}\text { Buffolo Creek } \\
\text { abovo Middle Fork }\end{array}$ & & 3.16 & & & & & $2-26-72$ & & 200 & 2 \\
\hline b/ (3) & $\begin{array}{l}\text { Buffolo Creek } \\
\text { below Sounders }\end{array}$ & & 6.05 & & & & & $2 \cdot 26-72$ & & 50,000 & of 40 \\
\hline b) (4) & $\begin{array}{l}\text { Buffalo Creck } \\
\text { beiow Stowe }\end{array}$ & & 21.0 & & & & & $2-26-72$ & & 13,000 & of 4 \\
\hline b/ $(5)$ & $\begin{array}{l}\text { Buffolo Creat } \\
\text { obovo Accoville }\end{array}$ & & 30.8 & & & & & $2-26-72$ & & 8,800 & of 2 \\
\hline b/ (6) & $\begin{array}{l}\text { Right Fork at } \\
\text { Accoville }\end{array}$ & & 9.49 & & & & & $2-26-72$ & & 500 & 2 \\
\hline \multirow{2}{*}{2030} & \multirow{2}{*}{$\begin{array}{l}\text { Guyandotte River } \\
\text { of Man }\end{array}$} & \multirow{2}{*}{$|928-7|$} & \multirow{2}{*}{762} & \multirow{2}{*}{$3-12-63$} & \multirow{2}{*}{24.78} & \multirow[b]{2}{*}{49,000} & \multirow{2}{*}{$>50$} & $2-25-72$ & 18.65 & 29,600 & 8 \\
\hline & & & & & & & & $2-26.72$ & 19.34 & $\frac{31,600}{n>0}$ & 10 \\
\hline \multirow{2}{*}{2036} & \multirow{2}{*}{$\begin{array}{l}\text { Guyondotte River } \\
\text { at Logan }\end{array}$} & \multirow{2}{*}{$1960-71$} & \multirow{2}{*}{836} & \multirow{2}{*}{$3-12-63$} & \multirow{2}{*}{34.98} & \multirow{2}{*}{55,000} & \multirow{2}{*}{$>50$} & $\frac{2-26-72}{2-25-72}$ & $\frac{19.02}{26.31}$ & $\frac{30,700}{33,900}$ & $\frac{9}{10}$ \\
\hline & & & & & & & & $\begin{array}{l}2-20-12 \\
2-26-72 \\
\end{array}$ & $\begin{array}{l}20.31 \\
27.28\end{array}$ & 36,100 & 13 \\
\hline 2040 & $\begin{array}{l}\text { Guyondotte River } \\
\text { of Branchland }\end{array}$ & $\begin{array}{l}1915-17 \\
1928-71\end{array}$ & 1226 & $3-13-63$ & 43.83 & 44,500 & 27 & $2-27-72$ & 41.63 & 40,800 & 20 \\
\hline 2070.2 & $\begin{array}{l}\text { Twelvepole } C_{r} \text {. } \\
\text { below Woyne }\end{array}$ & $\begin{array}{l}1928-31 \\
1946-71\end{array}$ & 300 & $2-4-39$ & & 22,000 & $>50$ & $2-26-72$ & 23.19 & 7,210 & 2 \\
\hline 2137 & $\begin{array}{l}\text { Tug Fork ot } \\
\text { Williamson }\end{array}$ & $1967-71$ & 932 & $3-12-63$ & 44.5 & & & $2-25-72$ & 29.75 & 23,000 & 3 \\
\hline 2140 & $\begin{array}{l}\text { Tug Fork at } \\
\text { Kormit }\end{array}$ & 1934.71 & 1185 & $3-13-63$ & 45.65 & 69,600 & 50 & $2-26-72$ & 0.25 & 46,800 & 8 \\
\hline
\end{tabular}

If Ratio of peok discharge to 50 year flood

b) Corresponds to site number shown on map (fig. 2)

of the dam on Middle Fork (fig. 28). The peak discharge of $31,600 \mathrm{cfs}$ (14 million gpm) related to this stage may not be reliable due to variable backwater. The peak discharge of 30,700 cfs (13.7 million gpm) occurring at gage height 19.02 was the result of natural drainage.

Peak flows, on the order of a 2-year flood, were produced on the North Fork above Middle Fork, on Buffalo Creek above Middle Fork, and on Right Fork at Accoville (table 3). These are all streams lying within Buffalo Creek basin but outside the influence of the large discharge produced by failure of the Middle Fork dam. These peak flows suggest that yields of from $60-100 \mathrm{cfs}$ per mile of drainage basin could have anticipated on Buffalo Creek had the dam on Middle Fork not failed. For example, it is estimated that the peak flow for Buffalo Creek below Saunders would have been approximately 400 cfs $(180,000$ $\mathrm{gpm}$ ) instead of the $50,000 \mathrm{cfs}$ (22 million $\mathrm{gpm}$ ) that was produced. A peak of this order of magnitude would also have been consistent with that produced by surrounding basins of the same size experiencing natural yields.

\section{PREVIOUS FLOODS}

Data given in table 3 show that peak flows for February 1972 for streams in southwestern West Virginia were quite low in comparison with previous maximum floods that have been recorded. Except for Buffalo Creek, peak discharges for February 1972 at stations in the Guyandotte River basin were generally well below those experienced in March 1963.

\section{THE FLOOD ON BUFFALO CREEK}

At about 8:00 a.m. on February 26, following the failure of coal-waste dam No. 3, 17.6 


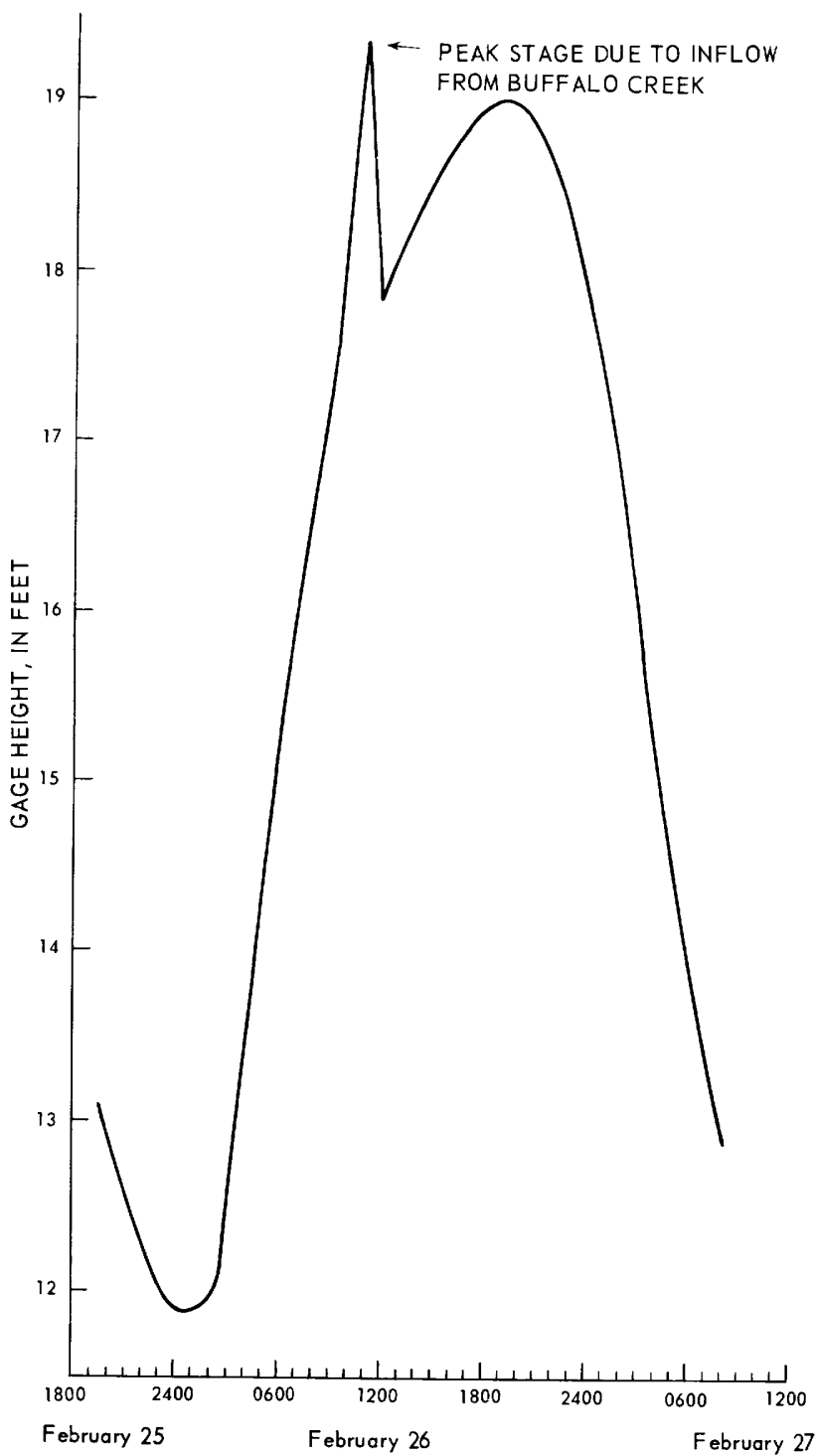

FIgURe 28.-The flood inflow from Buffalo Creek produced a sudden high peak of 19.34 feet on the gaging station record for Guyandotte River at Man at 11:00 a.m., February 26. Peak discharge was 31,600 cubic feet per second.

million cubic feet (132 million gal) of impounded water and sludge was released into Buffalo Creek. Eyewitnesses repoit that the contents of the dam were emptied into Buffalo Creek in 15 minutes or less. At the time of the dam failure, flow in Buffalo Creek was well below bankfull stage.

Indirect measurements were made on Buffalo Creek below Saunders, below Stowe, above Accoville and near Man to determine peak flows resulting from the release of water following the dam failure (fig. 2 and table 3). At Buffalo Creek below Saunders, 4,500 feet downstream from the mouth of the Middle Fork, the peak flow was computed as $50,000 \mathrm{cfs}$ ( $\approx 2$ million $\mathrm{gpm}$ ). Because this peak was not a natural occurrence, comparisons between it and other natural occurring flood peaks are not valid. However, it is interesting to note that at this site, a flood of this magnitude would be approximately 40 times that of a naturally occurring 50-year flood.

Peak discharges were greatly reduced due to valley storage as the flood wave moved downstream. This effect is shown in figure 29, where flood hydrographs were estimated on the basis of peak flow information obtained at indirect measuring sites and from flow duration information furnished by local residents. Attenuation due to valley storage reduced the peak flow to $13,000 \mathrm{cfs}$ ( 5.8 million $\mathrm{gpm}$ ) by the time the flood crest reached Stowe 6 miles downstream from the mouth of Middle Fork; although the total discharge past Stow'o was slightly greater than the total flow past Saunders, the floodflow took more than three times longer to travel past Stowe. The same attenuating effect from valley storage stretched out the floodflow all the way down Buffalo Creek; the floodflow that took only 15 minutes to pass Saunders took 2 hours to pass Man. Despite the attenuation, peak flow at Stowe was still unusually high, approximately four times that of a naturally occurring 50-year flood.

The effect of valley storage was les؟ pronounced above Accoville, 12 miles downstream from the mouth of Middle Fork, where the peak flow was determined as 8,800 cfs (3.9 million gpm). A peak flow of this magnitude, however, would still be approximately twice that of a naturally occurring 50-year flood. The peak flow at Man near the mouth of Buffalo Creek was estimated to be 7,500 cfs (3.4 million $\mathrm{gpm}$ ), slightly greater than the 59-year flood.

Time of Travel of the Flood Wave

Estimates of time of travel of the flood peak were made based on information furnish od by local residents. The flood wave passed through the Buffalo Creek valley in almost exactly 3 


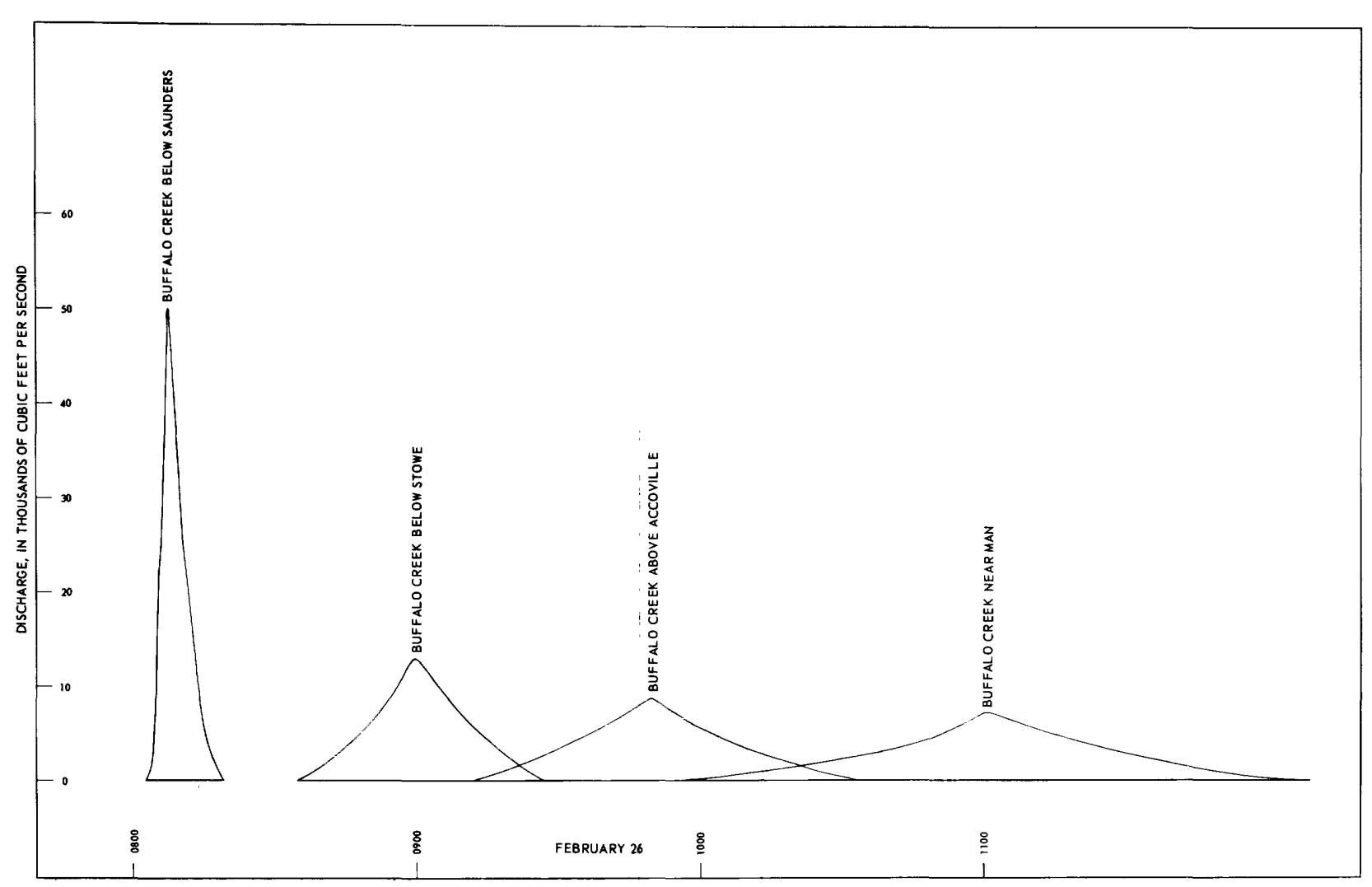

Figure 29.-Estimated flood hydrographs for Buffalo Creek below Saunders, below Stowe, above Accoville, and near Man on February 26, 1972.

hours, reaching the mouth of Buffalo Creek at Man at 11:00 a.m. on February 26. The traveltime versus distance relation for the flood wave is shown in figure 30 .

Mean velocities are estimated at 20 feet per second from Saunders to Pardee, 15-20 feet per second below Pardee to Lorado, and diminishing to about 10 feet per second near Accoville and to 5 feet per second or less near Man.

\section{Profiles}

Profiles of the flood wave and of the streambed were obtained for the 15-mile reach of Buffalo Creek from the mouth of Middle Fork to Man, from a survey of high-water marks at many sites throughout the reach (fig. 31). The fall, or total drop in elevation, from Saunders to Man is approximately 750 feet. The slope of the flood profile ranges from an average of 96 feet per mile in the reach from Saunders to Pardee to 33 feet per mile in the reach from Accoville to Man.

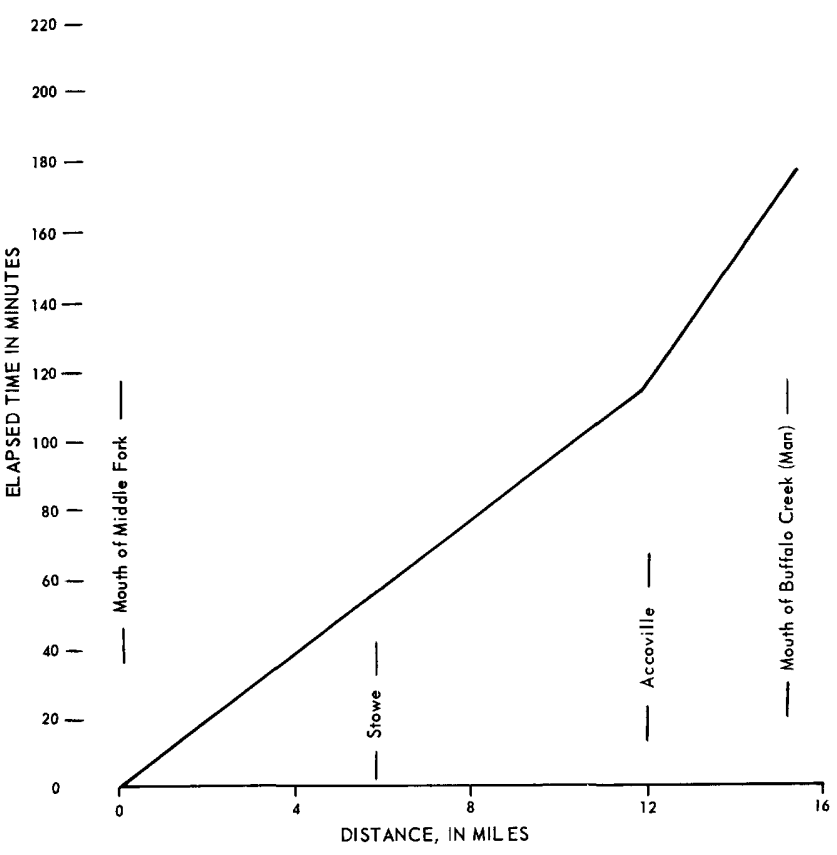

Figure 30.-Time of travel of the flood wave down Buffalo Creek from Middle Fork to Man. 

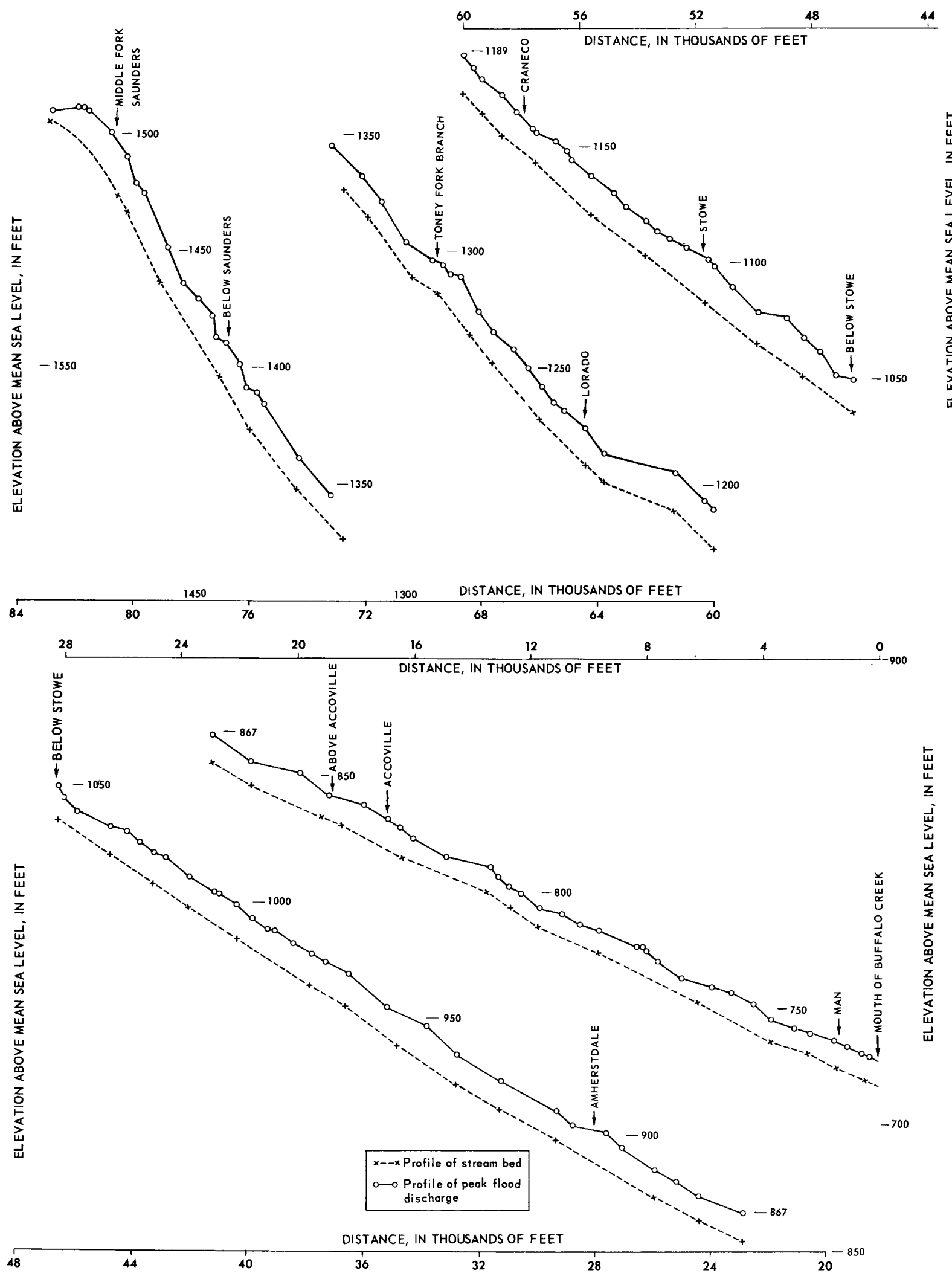

Figure 31.-Profile of the peak flood discharge and of the streambed, Buffalo Creek, Middle Fork to Man. 
Depth of Flow

The depth of flow in the stream channel at points along Buffalo Creek can be estimated from figure 31 by subtracting the bed elevation from the flood profile. The flood plain of Buffalo Creek ranges from 200 to 500 feet wide throughout the reach from Saunders to Man. Ground elevations on this flood plain can be determined by surveying to selected points on the flood plain from nearby bench marks. The depth of flooding on the flood plain can then be estimated by subtracting the ground elevation from the flood profile shown in figure 31. At the time of the peak, the depth of flow on the flood plain was approximately 12-10 feet deep from Saunders to Lorado, 9-6 feet deep from Craneco to Latrobe, and 5-2 feet deep from Robinette to Kistler.

\section{Scour and Deposition}

An estimated 6 million cubic feet of material was transported from the coal-waste banks in Middle Fork hollow and deposited downstream. Most of this material, consisting of coal waste, red dog, and slag, apparently was deposited in the reach from Saunders to Pardee. (The only significant signs of scours were also found in this reach, although there was evidence of scour at some kridge crossings farther downstream.) The streambanks and overflow plain from Saunders to Man were covered with a thin film of black sediment by the passage of the sludge-bearing water.

\section{REFERENCES}

Davies, W. E., 1967, Geologic hazards of coal refuse banks [abs.]: Geol. Soc. America, Program 1967 Annual Meetings, p. 43.

1968, Coal waste bank stabi"ty: Mining Congress Journal, v. 54, no. 7, p. 19-24.

Hennen, R. V., Reger, D. B., and F ice, W. A., 1914, Logan and Mingo Counties: West Virginia Geological Survey, p. 60-62, 124-125.

Latimer, W. J., 1915, Soil survey of Logan and Mingo Counties, West Virginia: U.S. Dept. Agriculture, Bureau of Soils, $30 \mathrm{p}$.

Park, W. R., Blankenship, J. C., Jr., Cook, J. O., Herndon, J. R., Shumate, J. L., 1972, Interim report of retaining dam failure, No. 5 Preparation Plant, Buffalo Mining Company, Division of the Pittston Company, Saunders, Logan Courty, West Virginia, February 26, 1972: U.S. Burealu of Mines, Mount Hope, W. Va., $12 \mathrm{p}$.

U.S. Department of Interior, Task Force to Study Coal Waste Hazards, 1972, Preliminary analysis of the coal refuse dam failure at Saunders, West Virginia, February 26, 1972: Washington, D.C., 42 p. 